http://economix.fr

\title{
The Quantification of Structural Reforms in OECD countries:
} A New Framework

Document de Travail

Balázs Égert

Working Paper

Peter Gal 2017-15

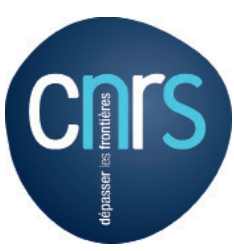

UMR 7235
Université de Paris Ouest Nanterre La Défense

(bâtiment G)

200, Avenue de la République

92001 NANTERRE CEDEX

Tél et Fax : 33.(0)1.40.97.59.07

Email : nasam.zaroualete@u-paris10.fr 


\title{
THE QUANTIFICATION OF STRUCTURAL REFORMS IN OECD COUNTRIES: A NEW FRAMEWORK
}

\author{
Balázs Égert* and Peter $\mathrm{Gal}^{\S 1}$
}

\begin{abstract}
This document describes and discusses a new supply side framework that quantifies the impact of structural reforms on per capita income in OECD countries. It presents the overall macroeconomic impacts of reforms by aggregating over the effects on physical capital, employment and productivity through a production function. On the basis of reforms defined as observed changes in policies, the paper finds that product market regulation has the largest overall single policy impact five years after the reforms. But the combined impact of all labour market policies is considerably larger than that of product market regulation. The paper also shows that policy impacts can differ at different horizons. The overall long-term effects on GDP per capita of policies transiting through capital deepening can be considerably larger than the 5- to 10year impacts. By contrast, the long-term impact of policies coming only via the employment rate channel materialises at shorter horizon.
\end{abstract}

JEL codes: D24; E17; E22; E24; J08

Keywords: structural reforms, product markets, labour markets, regulation, simulation, multi-factor productivity, investment, employment, per capita impact, OECD

* OECD, Economics Department; EconomiX at the University of Paris X-Nanterre; and CESifo. Email: balazs.egert@oecd.org

$\S$ OECD, Economics Department, Email: peter.gal@ oecd.org

1. The paper benefitted from useful comments and suggestions from Andrea Bassanini, Gilbert Cette, Alain de Serres, Sean Dougherty, Falilou Fall, Andrea Garnero, Alexander Hijzen, Catherine L. Mann, Fabrice Murtin and Jean-Luc Schneider. The views expressed in the paper are those of the author and do not necessarily reflect the opinions of the OECD or any other institution the authors are affiliated with. 


\section{Introduction}

1. This document describes and discusses a new simulation framework that quantifies the impact of structural reforms on per capita income. The overall medium- to long-term supply side impact is derived through components of the production function: multi-factor productivity, capital intensity and the employment rate. It builds on and extends the previous frameworks developed in the OECD's Economics Department, which include Bouis and Duval (2011); Barnes et al. (2013); and the long-term scenario model elaborated in Johansson et al. (2013) (Figures A1.2-A1.4). The framework used in ECO for the G20 and occasional country desk quantifications is based on Bouis and Duval (2011). In what follows, this will be referred to as the old framework.

2. In developing a new empirical framework for the quantification of the medium- to long-term impact of reforms, a number of objectives have been established at the outset (OECD, 2015). One is to extend the set of policy channels included in the framework to significantly broaden the range of quantifiable reforms. A second objective is to update the framework to cover the post-crisis period. A third objective is to improve the framework's internal consistency with respect to the country and time coverage, the empirical specification and econometric method used to estimate policy impacts. Fourth, countryspecific policy effects should be better taken into account. A final objective is a better integration of emerging market economies.

3. This document is a first step towards addressing the first three objectives. First, relative to the old framework, the number of policy variables and channels through which they influence GDP per capita is increased. Second, the new framework is based on relationships estimated over a period including the immediate post-crisis years (1985-2011), although it ends in 2011 due to the availability of some policy indicators. Third, internal consistency is increased by a considerable extent: new estimates for the three supply-side channels are based on a similar sample of countries and time span. The sample size is almost identical for the individual supply-side channels. ${ }^{2}$ The estimates are also based on a unified estimation framework (dynamic OLS in a panel setting).

4. This document could be viewed as work in progress. The estimated relationships will be reassessed, and new and more detailed policy variables will be added as need arises and new data become available. The estimation approach will be refined. Ongoing work looking into ways how to incorporate country-specific policy influences (Égert and Gal, 2016). The results presented in this document are based on average policy effects obtained on an OECD sample. Country-specific effects can be identified in a panel setting by conditioning the impact of individual policies on the stance of other policies or via policy interactions. This will allow for the incorporation of a potentially large set of additional policy areas including institutions and policy areas with limited time-series availability (e.g. subcomponents of the PMR indicator, housing market regulations or the rule of law indicator). Work on integrating EMEs into the quantification framework will also be completed in the next phase. This prompts two important questions: i.) an increased cross-country heterogeneity in the estimations, and ii.) a more detailed look at the role of the quality of institutions, which may determine the relation between policies and outcomes.

2. For instance, policy effects on labour market outcomes are analysed for specific policies (independently of other possibly relevant policies) on substantially different country samples. The effects of unemployment benefits, tax wedge and active labour market policies are taken from Bassanini and Duval (2006). The effect of childcare spending reported in Jaumotte (2003) is used. The first study covers 20 countries and the period 1982 to 2003, and uses OLS and SUR for estimation purposes. The second paper looks at 17 countries and 1985 to 1999 . It employs 2-stage least squares to estimate policy effects. For a more detailed comparison, see Tables A1.1 and A1.2. 
Finally, the estimates based on macroeconomic time series will be cross-checked with those obtained from using sector- and firm-level data to better control for potential endogeneity. ${ }^{3}$

5. This document is structured in three parts. Part 1 compares the main features of the old and the new frameworks. In particular, it discusses how the new framework improves on the old framework by i) incorporating more policy channels, ii) enhancing the internal consistency of the policy impacts, and iii) using updated estimates for them. Part 2 presents in detail how these new coefficient estimates are obtained. Part 3 finally sets out the new simulation framework and shows the impact of policy changes on per capita income and its supply-side components. It differs from typical OECD studies analysing specific policy impacts in a number of ways. First, the simulation framework considers the impact of a large number of policies by controlling for a wide range of other policies (including them in the regressions at the same time). Second, most projects typically look at the isolated relationship between policies on the one hand productivity, investment or labour market outcomes on the other hand. The framework is used to aggregate these effects into an overall impact on per capita income.

\section{A consistent framework to quantify the impact of structural reforms}

6. We follow previous OECD papers by assessing the impact of structural reforms on per capita income based on a production function approach (Barnes et al., 2013; Bouis and Duval, 2011; Johansson et al., 2013). In this paper, the influence of policies on GDP is assessed through their influence on its supply side components: multi-factor productivity (MFP), capital intensity and employment. Within this framework, the relationship between policies and these components is obtained from a range of crosscountry reduced-form panel regressions. The overall impact on GDP per capita is obtained by aggregating the policy effects of the various channels. ${ }^{4}$

7. The framework presented in this paper seeks to improve on a number of dimensions compared to previous OECD studies. First, a considerably larger number of policy determinants are analysed for MFP and employment and policy determinants of capital deepening are introduced. Second, internal consistency is improved in three ways. To start with, supply-side channels are used in a consistent manner: different levels of disaggregation of the supply side components are not mixed across policy areas (e.g. employment for some policies, the labour force participation and unemployment rate for others). In addition, econometric estimates are obtained using the very same up-dated dataset (SPIDER dataset) for as many countries as possible (25 for the employment rate and above 30 for MFP and capital deepening) and estimation technique. Finally, changes in policy measures and the horizons at which their impact is measured are standardised. The last major improvement relates to the updating of the coefficient estimates. We make use of econometric estimates covering the post-crisis period (mostly until 2011-2013) for all three supply-side channels (MFP, capital deepening and the employment rate).

3. Macroeconomic estimates are well- suited to quantify the overall macroeconomic effects of policies. But policy effects may be better identified in sector- or firm-level datasets. However, computing overall macroeconomic policy effects using sector- and firm-level estimates require specific assumptions: most of them obtain partial equilibrium results and results that are differential in nature (identifying from differences between two groups) and not aggregate economy-wide effects.

4. Appendix 1 provides a detailed comparison of the old and new frameworks. 


\section{Empirical estimates used in the simulation framework}

8. The baseline estimates used in the simulation framework are taken from Egert (2016a, 2016b) and Gal and Theising (2015). They are summarised hereafter. ${ }^{5}$

\subsection{Multi-factor productivity}

9. We calculate aggregate MFP as the residual of output once capital and labour are accounted for. Human capital is included in our measure of MFP: MFP series, which exclude human capital (output minus human and physical capital and labour) are implausible: a decline over decades in countries close to the frontier, and the USA being far from the frontier (see details in Égert, 2016a).

10. The policy determinants of MFP are taken from Égert (2016a) and the main results are summarised in Table 1 (columns 1 to 3 ). These results suggest that a strong negative relationship can be identified between product market regulations, captured by the overall ETCR indicator (and its subcomponents barriers to entry and public ownership) and MFP mostly if only country but no year fixed effects are used. ${ }^{6}$ If both country and time fixed effects are included in the regressions, only the coefficient estimate on public ownership is found to be statistically significant, overall ETCR and barriers to entry have large standard errors for the full sample. When using a subsample, given by data available on general spending on basic research (rather than business spending on R\&D funded by industry used for the large sample), the overall ETCR indicator and its subcomponents become again negative and statistically significant.

11. None of the labour market regulation indicators ${ }^{7}$ are statistically significant when added one by one to the baseline regression. ${ }^{8}$ But ALMP becomes statistically significant if used in logs. The positive

5. It should be noted that a number of sensitivity checks are carried out in Egert (2016a, 2016b) and Gal and Theising (2015). They confirm that the results summarised hereafter are fairly robust to alternative specifications regarding time and country coverage, different controls and estimation methods.

6. The MFP and ETCR series have common trends captured by year fixed effects. These trends are strongly correlated with each other. The correlation between the time fixed effects of MFP and the demeaned overall ETCR series is 0.72 (the series are also demeaned in the regressions including country fixed effects). When we compare the time fixed effects in the MFP and ETCR series, the correlation is 0.77 . This is not surprising as time fixed effects explain about $89 \%$ of the variation of the demeaned overall ETCR series. When decomposing the overall ETCR indicator into i.) barriers to entry and ii.) public ownership, public ownership survives the inclusion of year fixed effects. This variable could potentially be used for the purpose of quantification (at the expense of covering fewer policy areas).

7. Three labour market regulation indicators are used: EPL for permanent contracts. ALMP spending and the unemployment benefit replacement ratio.

8. The finding that EPL is statistically not significant stands somewhat in contrast with the literature using sector- and firm-level data relying on difference-in-difference approaches. For instance, Bassanini et al. (2009) finds for a set of 16 OECD countries from 1982 to 2003 that country-level EPL is associated with lower MFP growth in sectors with higher layoff rates. Rincon-Aznar and Siebert (2012) show the negative relation to hold for manufacturing sectors but not for the services sectors (Table 5, on a somewhat different sample: 11 OECD countries from 1984 to 2007). Using firm-level data for the USA, Autor et al. (2007) report mixed evidence on the negative relation between employment protection (good faith exception) and the level of MFP: the coefficient estimates are negative but only one coefficient in two is precisely estimated (Table 8, panel 1, first row). Dougherty et al. (2011) show that state-level employment regulation lowers MFP levels in Indian firms operating in more-labour intensive industries. However, our results cannot be fully compared with these results. A difference-in-difference approach identifies the extent to which employment regulation affects differently sectors or industries with different characteristics. But it does not inform us whether employment protection is good or bad, neither the size of the impact for overall 
sign on ALMP may indicate that more spending on ALMP helps labour reallocation towards more productive uses by reducing skill mismatches (Adalet-McGowan and Andrews, 2015).Adding year fixed effects to the regressions switches off the innovation intensity variable. In the simulations, estimates obtained using country fixed effects only will be used.

\subsection{Capital deepening}

12. The policy determinants of capital deepening are taken from Égert (2016b). The results are summarised in Table 1 (columns 4 and 5). In the baseline specification, $\mathrm{K} / \mathrm{Y}$ is regressed on the user cost of capital (decomposed into relative investment prices, the real interest rate and corporate taxes) and product market regulation. Labour market policies are added to the regressions in a later stage. The results show that the corporate taxes-to-GDP ratio and the relative investment price variable bear the expected negative sign and are statistically significant. But the real interest rate is found to be only weakly related to the capital stock. To be fully consistent with theory, we keep all three components of the user cost of capital in the specifications augmented by structural policy indicators.

13. Product market regulation, measured by the ETCR indicator, shows a fairly robust negative relationship with the capital stock series. It is robust to alternative (smaller) country samples and time coverage (excluding the crisis). Finally, the results do not change ostensibly if the regressions are carried out on a reduced common sample covering all labour market policy indicators as well (Table 1).

14. The employment protection legislation (EPL) indicator has a strong and quantitatively important negative relationship to the capital stock. Its coefficient estimate is precisely estimated for both the level and log-linear specifications. The estimated elasticities indicate that a one-step increase in EPL is associated with a decline of about 0.2 percent in the capital stock-to-output ratio. ${ }^{9}$ It should be noted that the negative relation between the ETCR indicator and the capital stock remains statistically significant and of the same magnitude (Table 1).

MFP. It would require additional assumptions regarding the impacts on the presumably less affected industries or firm groups (control group). In the macro estimates, the coefficient on EPL is also negative and statistically significant if it is identified both along the within and between dimensions, i.e. when EPL's cross country variation is also taken into account in regressions not including country fixed effects (Égert, 2016a).

9. This negative relationship is robust to alternative country coverages (for narrower samples composed of more developed OECD countries) and to the definition of the capital stock (real capital stock, capital stock/output, capital stock/workers). This result needs qualification. The effect of EPL on investment is not clear-cut in the existing body of research. The literature reports no evidence that labour market regulation has any impact of investment at the macroeconomic level and for several OECD countries (Kerdrain et al, 2010). There is mixed evidence on the relation between capital stock and labour market regulation at the firm level. There is evidence for European firms that more stringent EPL reduces investment per worker and capital per worker (Cingano et al., 2010). By contrast, for US firms, research suggests higher firing costs (wrongful discharge exceptions) are linked to higher capital stock and capital-to-labour ratios. But the effect becomes negative when state-specific trends are used. A rise in capital may be related to a correction of an earlier downturn and that the introduction of more stringent firing regulations followed a rise of the capital-to-labour ratio (Autor et al. 2007). For Italian firms, estimation results show that the introduction of unjust-dismissal costs raises the capital-to-labour ratio in firms with less than 15 employees, compared to larger firms (Cingano et al., 2015). 
Table 1. MFP and investment: long-term coefficient estimates used in the simulations

\section{Explanatory variables}

\begin{tabular}{|c|c|c|c|c|c|}
\hline \multirow[t]{2}{*}{ 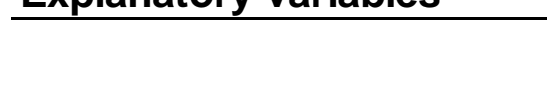 } & \multicolumn{3}{|c|}{ Multi-factor productivity } & \multicolumn{2}{|c|}{ log(capital stock/output) } \\
\hline & (1) & (2) & (3) & $(4)$ & (5) \\
\hline \multicolumn{6}{|l|}{ Product market regulation } \\
\hline ETCR aggregate & $-0.037^{\star \star}$ & & $-0.047^{* *}$ & $-0.035^{\star *}$ & $-0.025^{\star *}$ \\
\hline ETCR public ownership & & $-0.027^{\star *}$ & & & \\
\hline \multicolumn{6}{|l|}{ Labour market policies } \\
\hline $\log$ ALMP & & & $0.029^{\star *}$ & & \\
\hline EPL & & & & & $-0.152^{\star *}$ \\
\hline \multicolumn{6}{|l|}{ Intermediate outcomes } \\
\hline trade openness (size adjusted) & $0.007^{\star \star}$ & $0.008^{* *}$ & $0.006^{\star *}$ & & \\
\hline business exp. On R\&D by industry & $0.071^{\star *}$ & $0.059^{\star *}$ & $0.047^{\star *}$ & & \\
\hline \multicolumn{6}{|l|}{ Elements of the user cost of capita } \\
\hline log relative investment prices & & & & $-0.377^{\star *}$ & $-0.608^{\star \star}$ \\
\hline long-term real interest rate & & & & 0.002 & $0.004^{*}$ \\
\hline corporate taxes/GDP & & & & $-0.024^{* *}$ & $-0.026^{\star *}$ \\
\hline error correction term & $-0.033^{* *}$ & $-0.043^{* *}$ & $-0.052^{* \star}$ & $-0.026^{\star *}$ & $-0.022^{\star \star}$ \\
\hline Adjusted R-squared & .952 & .959 & .964 & .919 & .947 \\
\hline Country / year fixed effects & Yes / No & Yes / Yes & Yes / No & Yes / Yes & Yes / Yes \\
\hline No. of observations / countries & 755 / 34 & 755 / 34 & $570 / 32$ & 705 / 32 & $600 / 31$ \\
\hline Years & $1985-2011$ & 1985-2012 & $1985-2013$ & $1985-2013$ & 1985-2013 \\
\hline
\end{tabular}

Note: Estimates based on using the dynamic OLS (DOLS) estimator with one lag and one lead. The MFP regressions include human capital and output gap and the capital deepening regression output gap as control variables. Standard errors are heteroscedasticity robust. ${ }^{* *}$ and ${ }^{*}$ denote significance at the $5 \%$ and $10 \%$ level, respectively.

\subsection{Employment rate}

15. Policy determinants of the employment rate are taken from Gal and Theising (2015), who build on previous work from the OECD Reassessed Jobs Strategy (Bassanini and Duval, 2006). The impact of policies on the aggregate employment rate is derived from estimation results obtained for four demographic groups (youth, prime age women and man; and the elderly). Such a breakdown makes it possible to capture more policies than regressions focusing directly on the overall employment rate or a breakdown by skill levels. Estimation results, summarised in Table 2, show that among tax-benefit and activation policies, lower unemployment benefit replacement rates, increased spending on active labour market policies (ALMP), lower labour tax wedges all tend to boost employment. These findings broadly confirm existing results but based on an updated dataset and on a somewhat different methodology. ${ }^{10}$. Regarding wage-setting institutions, the excess coverage of wage agreements, its interaction with the tax wedge and the level of minimum wage tend to affect employment rates negatively. Product market regulation captured by the ETCR indicator correlates negatively with the aggregate employment rate. Finally, while the EPL indicator hase no clear robust relationship with the aggregate employment rate (Table A4.3), it does have a heterogeneous impact across various segments of the population. This makes

10. The statistically significant relation between these policies and the overall employment rate (Table A4.2) are robust to various sensitivity checks, including different estimation methodologies, control variables and a time period covering only the pre-financial crisis period (Table 10-12 and D1-D3 in Gal and Theising, 2015). Nevertheless, jackknifing the sample, i.e. dropping one country at a time from the sample, shows some sensitivity to the country coverage. 
aggregate effects potentially dependent on the composition of the working age population by skills and demographic groups.

16. Indeed, some of the other policy effects also show significant and intuitive heterogeneities across segments of the population

- Higher unemployment benefit replacement rates affect most negatively the employment of the elderly and the low educated;

- ALMP spending has positive effects for each segments of the population, mostly so for the youth;

- Minimum wage impacts are stronger for the youth than for prime age men and the elderly. ${ }^{11}$ The minimum wage impacts are even stronger for prime wage women. ${ }^{12}$

- Stricter employment protection legislation tends to decrease female employment rates, although this result is not robust to the exclusion of family policies. Effects on men are ambiguous. It also has opposing effects on the low educated (lowering employment) and on the highly educated (increasing employment) (Table A4.4). The explanation can be that stricter EPL may hold back less the hiring of highly qualified workers (they are more likely to provide a better match for the firm) and impacts less their firing (which may be more costly). These opposing effects across groups of the population help to explain why it is difficult to find robust aggregate effects;

- $\quad$ Raising the legal retirement age increases labour force participation for the elderly;

- More spending on in-kind family benefits such as childcare and longer maternity leaves increase employment rates of the working-age female population.

11. The magnitude of the estimated impact ( -0.3 for the youth) seems consistent with studies showing elasticities of -0.1 to -0.2 (see recent survey by Neumark, 2015 and OECD, 2015b). This is because we use the Kaitz index (median to minimum wage), which in our sample averages at $50 \%$ (Table 5, Gal and Theising, 2015). Hence 1 percentage point (pp) increase in it translates into a 2 pp increase, on average, for the minimum wage level. Therefore coefficients obtained when using the level of the minimum wage should be multiplied by two to make them comparable with our coefficients.

12. Our coefficient estimates for prime-age women are larger than those reported in the literature using similar datasets (Addison and Ozturk, 2012). The differences may be due to different model specification and data coverage. Therefore, care should be taken when using these estimates for quantification. 
Table 2. Employment rate-long-term coefficient estimates

Dependent variable: employment rate

\begin{tabular}{|c|c|c|c|c|}
\hline & Youth & $\begin{array}{c}\text { Prime age } \\
\text { women }\end{array}$ & $\begin{array}{c}\text { Prime } \\
\text { age men }\end{array}$ & Elderly \\
\hline & $(1)$ & $(2)$ & (3) & $(4)$ \\
\hline \multicolumn{5}{|l|}{ Tax-benefit and activation policies } \\
\hline UE benefit replacement rate & $-0.183^{\star *}$ & $-0.204^{\star *}$ & $-0.147^{\star *}$ & $-0.343^{\star \star}$ \\
\hline ALMP spending on unemployed, as \% of GDP/capita (HP-trend) & $0.147^{\star \star}$ & $0.092^{\star \star}$ & $0.047^{\star *}$ & $0.063^{\star *}$ \\
\hline Tax wedge (single, no ch.) & $-0.866^{* *}$ & & & \\
\hline Tax wedge (couple, 2 ch.) & & 0.004 & $-0.274^{\star *}$ & $-0.260^{\star \star}$ \\
\hline \multicolumn{5}{|l|}{ Wage setting institutions } \\
\hline Excess coverage & 0.072 & $-0.171^{\star *}$ & 0.025 & 0.105 \\
\hline Excess coverage ${ }^{*}$ Tax wedge (single, no ch.) & $-3.627^{\star *}$ & & & \\
\hline Excess coverage * Tax wedge (couple, 2 ch.) & & $-0.938^{\star *}$ & 0.079 & $0.623^{*}$ \\
\hline Minimum wage (\%median) & $-0.311^{* *}$ & $-0.421^{* *}$ & 0.043 & -0.093 \\
\hline \multicolumn{5}{|l|}{ Labour and product market regulations } \\
\hline EPL regular contracts & 1.599 & $-2.746^{*}$ & -0.569 & 1.710 \\
\hline ETC regulation & 1.032 & $-1.533^{\star *}$ & 0.232 & 0.630 \\
\hline \multicolumn{5}{|l|}{ Policies primarily affecting women } \\
\hline Family benefits in cash (\% of GDP) & & -0.967 & & \\
\hline Family benefits in kind ( $\%$ of GDP) & & $4.698^{\star *}$ & & \\
\hline Number of weeks of maternity leave & & $0.265^{* *}$ & & \\
\hline \multicolumn{5}{|l|}{ Pension system - primarily affecting the elderly } \\
\hline Legal age for pensions (total) & & & & $0.851^{* *}$ \\
\hline Error correction term & $-0.303^{\star \star}$ & $-0.145^{\star \star}$ & $-0.294^{\star *}$ & $-0.160^{\star *}$ \\
\hline Adjusted R-squared & .978 & 0.960 & .907 & .977 \\
\hline Country / year fixed effects & Yes / Yes & Yes / Yes & Yes / Yes & Yes / Yes \\
\hline No. of observations / countries & 422 / 25 & $420 / 25$ & $420 / 25$ & 422 / 25 \\
\hline Years & $1987-2010$ & $1987-2010$ & $1987-2010$ & $1987-2010$ \\
\hline
\end{tabular}

Note: Estimates based on using the dynamic OLS (DOLS) estimator with one lag and one lead. Heteroskedasticity and autocorrelation robust (Newey-West) standard errors are shown in parentheses. The regressions also include the output gap, government employment, the government budget balance, a measure of average educational attainment (adjusted mean years of schooling) and an indicator for the presence of minimum wages as further controls. See more details and Gal and Theising (2015). ** and ${ }^{*}$ denote significance at the $5 \%$ and $10 \%$ level, respectively.

\section{The new simulation framework}

17. This section illustrates how the new quantification framework. Box 1 describes how policy impacts on the three supply-side channels can be aggregated to total per capita income effects.

\section{Box 1. Calculating total policy impacts on per capita income}

Theoretical considerations

In the new framework, similarly to previous frameworks, structural policies affect per capita income through the supply side components. The appropriate aggregation across the components is straightforward in a standard neoclassical model with a Cobb-Douglas aggregate production of the following form. 


$$
Y=K^{\alpha}(h L)^{1-\alpha}, \quad 0<\alpha<1
$$

with h denoting labour-augmenting (Harrod-neutral) technological progress. Note that the empirical construction of the MFP measure that is used for the estimations relies on the formulation in equation (1). ${ }^{13}$ However, under the assumption of constant returns to scale, equation (1) can be rewritten in the following way:

$$
Y=M F P\left(K^{\alpha} L^{1-\alpha}\right)
$$

where there is a very close link between multi-factor productivity (MFP) and h: $M F P=h^{1-\alpha}$. Introducing per capita measures and after some rearrangements, per capita income can be expressed as a function of MFP, the capitaloutput ratio $(K / Y)$ and the employment rate $\left(L / N_{w a}\right)$ :

$$
\ln \left(\frac{Y}{N_{p o p}}\right)=\frac{1}{1-\alpha} \ln (M F P)+\frac{\alpha}{1-\alpha} \ln \left(\frac{K}{Y}\right)+\ln \left(\frac{L}{N_{w a}}\right)+\ln \left(\frac{N_{w a}}{N_{p o p}}\right)
$$

where $N_{\text {pop }}$ and $N_{w a}$ stand for total population and working age population, respectively.

The advantage of this formulation is that in a standard setting, all components are separable and independent from each other. Specifically, the capital-output ratio does not depend on either productivity or employment, neither is the employment rate influenced by productivity or capital. ${ }^{14}$

For simulating the effects of changes in policies, the above equation will be used in growth rates:

$$
\Delta \ln \left(\frac{Y}{N_{p o p}}\right)=\frac{1}{1-\alpha} \Delta \ln (M F P)+\frac{\alpha}{1-\alpha} \Delta \ln \left(\frac{K}{Y}\right)+\Delta \ln \left(\frac{L}{N_{w a}}\right)+\Delta \ln \left(\frac{N_{w a}}{N_{p}}\right)
$$

where $\Delta$ captures differences over time, which can be interpreted as percentage changes. As mentioned above, MFP in our empirical framework uses the Harrod-neutral specification. Hence (4) can be rewritten as follows:

$$
\Delta \ln \left(\frac{Y}{N_{\text {pop }}}\right)=\Delta \ln (h)+\frac{\alpha}{1-\alpha} \Delta \ln \left(\frac{K}{Y}\right)+\Delta \ln \left(\frac{L}{N_{w a}}\right)+\Delta \ln \left(\frac{N_{w a}}{N_{p}}\right)
$$

Similarly to the calculation of MFP a standard value for capital elasticity is set in the simulations $(\boldsymbol{\alpha}=0.33)$. The last term capturing the share of working age population will be assumed to be unchanged over the simulation horizon. Alternatively, demographic projections by the United Nations could be used over the projection horizon (long-term scenarios project of the OECD, Johansson et al., 2013).

Practical considerations

13. MFP used for the estimations is calculated as follows:

$$
\ln \left(M F P_{t}\right)=\ln \left(Y_{t}\right) /(1-\alpha)-\ln \left(L_{t}\right)-\ln \left(C L F_{t}\right)-\alpha /(1-\alpha) \ln (K)_{t},
$$

where $C L F$ adjusts labour input for people working but not living in the country or those working abroad for domestic companies $\alpha=0.33$, the standard value in the literature and fixed across countries and over time for ensuring comparability in a simple manner.

14. Considering capital intensity, when $r$ is the real interest rate, the capital-output ratio in equilibrium is given by $\frac{K}{\mathrm{Y}}=\frac{\alpha}{\mathrm{r}}$. In a more elaborate setting, the real interest rate can be replaced by the user cost of capital, which Includes the relative price of investment goods and corporate taxes as further determinants. In addition, excessive regulation can introduce frictions that suppress capital accumulation - a mechanism that can be captured by product and labour market regulation indicators.

As for the employment rate, both labour supply and labour demand determinants enter as policy channels in equilibrium (hence no need to include wages or productivity on top of them). 
MFP and capital deepening are measured in logarithms, while the employment rate is measured in percentage points (between 0 and 100). The simulation framework requires that the reform impacts are expressed in log-points for each supply side component, Percentage point changes in the employment rate are thus transformed into logpoints by dividing the changes in the employment rate by the latest observed employment rate for the working age population $L / N_{w a}$ (which was $67 \%$ in 2013 , averaged across all countries in the sample):

$$
\Delta \ln \left(L / N_{w a}\right)=\frac{\Delta\left(L / N_{w a}\right)}{L / N_{w a}}
$$

Another issue about aggregation is how to obtain the aggregate employment effect from the demographic and skill groups of the population. Policy effects for these groups are aggregated using the groups' weight in the working age population. For the illustrative simulations presented in this paper, the population structure of the average OECD country is used in the latest available year (Table A6.2).

\subsection{Choosing the size of policy changes for illustrative purposes}

18. One needs to determine the magnitude of changes in the structural policy indicators to quantify the impact of structural policies on per capita income. Ideally, in each case, one should use details on planned policy changes and translate them into the policy indicators used for the estimations. In practice, this is not always possible. Details are not always sufficient and if they are, it is not always easy to map them into our policy indicators.

19. For such cases and for illustrative purposes, we define a reform measure for each policy, which is based on policy changes observed in the past. More specifically, reforms are determined as the average improvements in the policy indicators in two-year windows. Only those consecutive years are used during which policy indicators moved into the reform direction in both years. Appendix 5 discusses alternative reform scenarios. It is important to stress that the impact of reforms is linear: if reform intensity (the change in the policy indicator) doubles, the impact on per capita income will also double.

\subsection{Obtaining policy effects over different horizons}

20. Policy effects identified by the coefficient estimates are the long-run effects (Tables 1 and 2). This implies full convergence, which can take a very long time, depending on the estimated speed of adjustment parameters. For MFP and capital deepening, the estimated error correction terms are estimated in the range of -0.03 to -0.05 , and for employment, they are around - 0.2 (Tables A4.1A4.2 in Appendix 4). A speed of adjustment coefficient of $\rho=-0.05$ implies that $90 \%$ of the convergence occurs after about 45 years. ${ }^{15}$ This long term convergence can be speeded up if the short term effect is large and points to the same direction. Such an initial "boost" is found for the ETCR impact on MFP, for instance (see Figure 1). Policymakers are typically interested in policy impacts at shorter time horizons. Therefore, policy impacts are also calculated and presented for 5 and 10 years after the reforms took place.

21. The adjustment path is calculated using the estimated error correction term and the contemporaneous, short run policy effect from the error correction model. The adjustment path uses estimates of the short-run effects and the speed of adjustment terms from Tables A4.1-A4.2 in Appendix 4. The overall impact will therefore depend on the adjustment path to the long-run equilibrium and the number of years considered after the policy changes. To compute policy impacts over the desired horizon,

15. $\ln (1-0.9) / \ln (1-0.05) \approx 45$ years. The half-life, i.e. the time over which half of the convergence to the new long-run equilibrium happens can be calculated as $\ln (1-0.5) / \ln (1-0.05) \approx 13.5$ years. 
the convergence path for each policy is evaluated for each supply-side channel. These effects are then aggregated across policies and supply side components, in accordance with equation (5) in Box 1.

22. The policy effects are linear with respect to changing the size of the reform measure, but they are non-linear depending on the time horizon over which they are evaluated. Put differently, the impact of reforms is twice as much if the reform shock is twice as large. However, the impact 5 years after reforms occurred can be different from the half of the impact predicted for 10 years after the reforms were introduced. As described above, the effect is determined by the shape of the adjustment path to the total long term effect. Figure 1 shows these adjustment paths and the resulting non-linear impacts in terms of different horizons for two different policies. The adjustment path for an ETCR impact on MFP is slow and decelerating. Adjustment of an ALMP impact on the employment rate is characterised by an initial overshooting and then a gradual return to the long-run equilibrium.

Figure 1. Adjustment path towards the long-run impact: two examples

The impact of a unit ETCR-reform on MFP

unit reform: -0.31 point

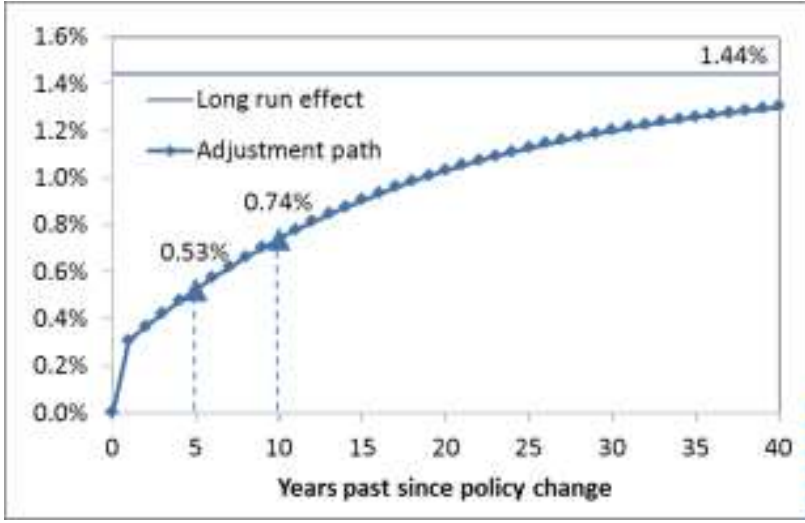

The impact of a unit ALMP reform on the employment rate (in percentage points) unit reform: 3.18 percentage points

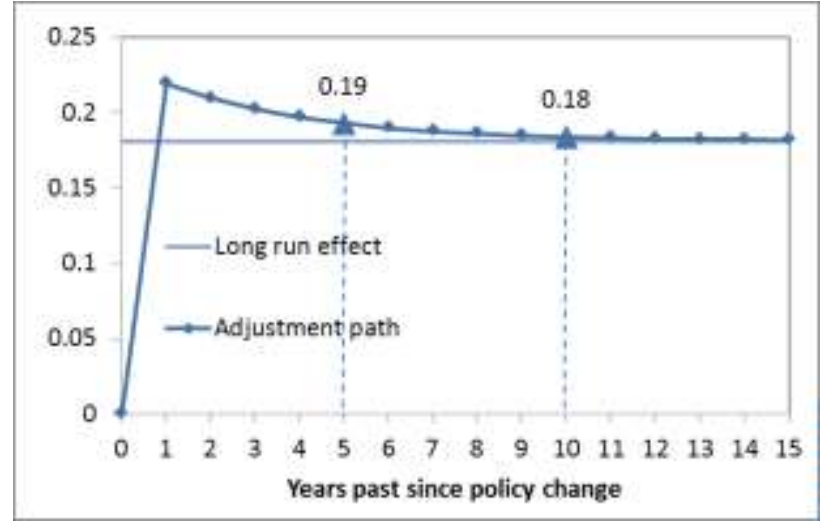

Note: ETCR stands for Energy, Transport and Communication Regulation. The size of the reforms are measured by the average changes of the indicators to a more favourable direction, observed over two consecutive years, across all OECD countries in the sample and years (1985-2013). The estimates for the long- and short run effects of the policies and the convergence parameters are taken from column 3 of Table 1 and Table A4.1 for MFP and from Table A4.3 for the employment rate. For each year $t$ following the policy change, the adjustment path of the policy effect is $\left[1-(1+\rho)^{t-1}\right](\beta x-\gamma x)+\gamma x$, where $\rho, \beta$ and $\gamma$ are the estimates for the speed of adjustment, the long run and the short run impact of the policy, and $x$ is the size of the reform shock.

\subsection{Simulation results}

23. This section presents the impact of policies on per capita income levels. The overall impact mostly reflects average effects across countries, as country-specific effects play a much smaller role in the new framework at the current stage.

\subsubsection{Average country effects in the new framework}

Overall impact on per capita income 5 years after the policy changes took place (Figure 2 and Table 3):

- Product market regulation measured by the ETCR indicator has the largest overall direct policy impact: $0.7 \%$. This is because ETCR influences per capita income through all three supply-side channels (productivity, capital deepening and the employment rate). The impact through MFP is 0.5 . This is comparable with the impact of other policies. For instance, the impact of increased ALMP spending, a reduction in tax wedge and in the minimum wage or in the number of 
maternity leave weeks ranges from $0.36 \%$ to $0.49 \%$ (Table 3, column 2). The influence of trade openness is similar in magnitude of that of ETCR. However, it requires further empirical work to pin down through which policies openness impact on MFP and thus on per capita income.

- Some policies have only a minor impact on per capita income levels. For instance, raising the legal retirement age, increasing business spending $\mathrm{R} \& \mathrm{D}$ funded by industry and cutting excess coverage add about $0.1 \%$ to per capita income when using past positive policy changes over two consecutive years (Table 4, column 2). The small impact of R\&D may seem puzzling. There is some evidence that less developed OECD countries may benefit more from technology diffusion and adoption through the trade channel and that innovation intensity (more spending on R\&D) may be more important for more advanced OECD countries (Égert, 2016a).

- The overall impact of all labour market policies is considerably larger than the overall effect of ETCR and the remaining policies (corporate taxes and R\&D spending). Nevertheless, adding up the effect of all labour market policies implies that reforms are carried out simultaneously in all quantifiable policy areas, which is rather implausible in practice.

- Table 3 (and Tables A6.3 to A6.4 containing detailed impacts on longer horizons) can indeed provide precious help for policy makers for the elaboration of comprehensive structural reform packages. Depending on the ease with which reforms can be implemented, policies could be picked to reach policy objectives in terms of overall impact on per capita income.

24. Comparing the impact of policies across different horizons: 5 and 10 years after policy changes and the long-run effect (Table 4):

- For some policies, the overall long-term effects on GDP per capita can be considerably larger than the 5- to 10-year impacts. These policies include ETCR, EPL and ALMP spending.

- The total impact of other policies, mostly labour market policies transiting only via the employment rate channel, materialises at shorter horizon. Hence, the impact at different horizons - reported in Table 6 - are similar in magnitude.

25. Impact of policies on the separate supply-side channels (Figure 3) ${ }^{16}$ :

- Different policies have different impacts on the separate supply-side channels. For instance, corporate taxes have a much larger impact on investment compared to product market regulations (ETCR). The impact of legal retirement age on the employment rate is roughly 5 times smaller than those found for minimum wages, maternity leave weeks or ALMP spending (Figure 4).

- The impact of EPL reform on the employment rate is subject to large uncertainties. The effect is very small and negative if estimates from aggregate employment equations are used, reflecting the mechanism that in the short run, less strict EPL can induce more firings. However, when the overall impact is obtained by aggregating the impacts across separate segments of the population - either by educational attainment levels or by demographic groups - positive effects can be identified, up to half a percentage point. Uncertainties about the average employment impact of EPL have also been emphasised in earlier findings in the literature (Boeri et al, 2015).

16. In addition to the baseline results based on demographic groups, the predicted impacts for the employment rate and the core set of policies are shown for two alternative approaches: i.) results obtained for the overall employment rate; and ii.) results obtained for skill groups. 
- $\quad$ Some policy areas (family benefits, pension age) can be assessed and included in the framework only by demographic groups. Hence as a benchmark in future quantification exercises, the effects found when aggregating across demographic groups could be used.

Figure 2. The impact of reforms on GDP per capita 5 and 10 years after the reforms

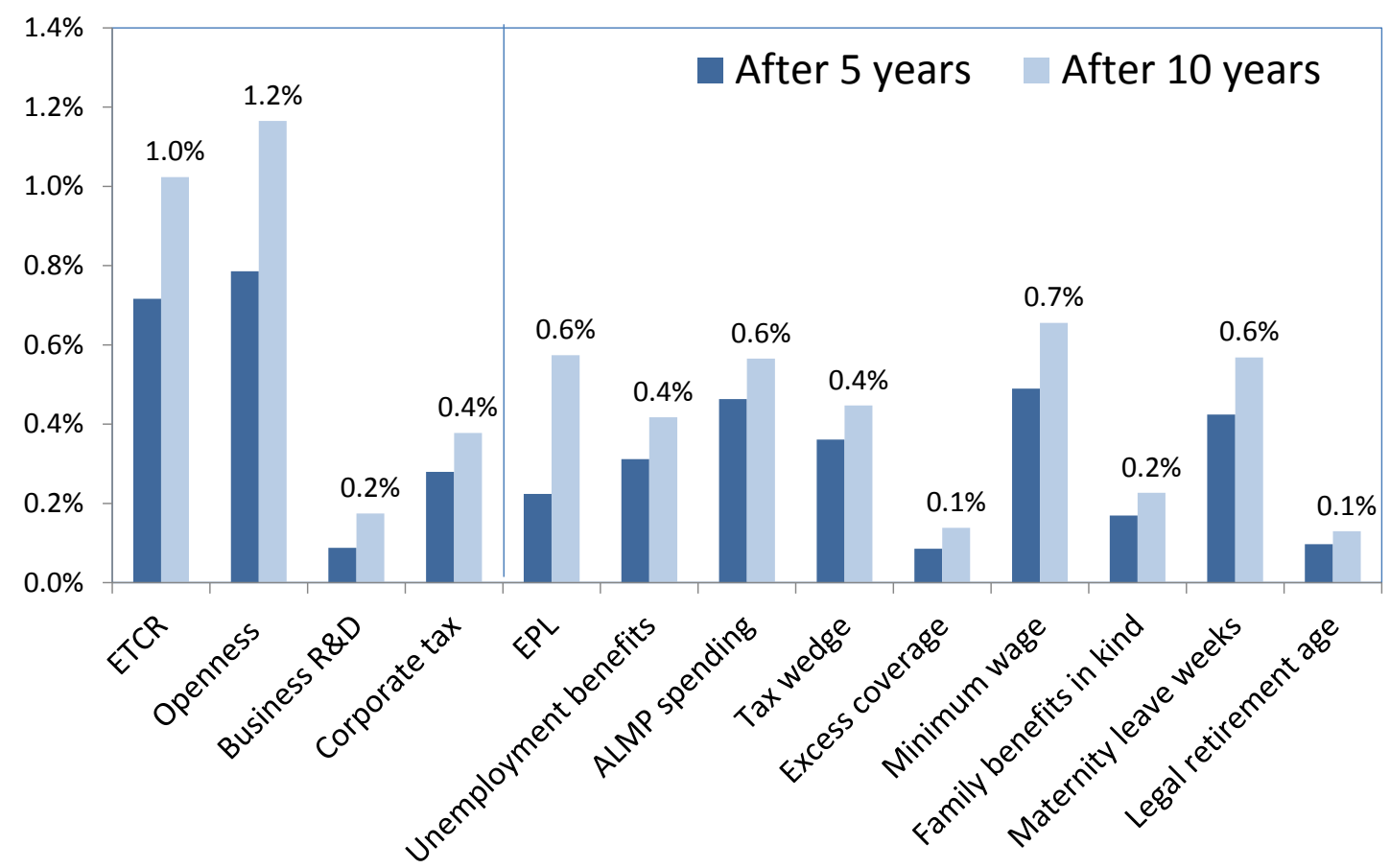

Note: Typically observed reforms are measured here by the average of all beneficial two-year policy changes that were observed over two consecutive years in the sample. 
Table 3. The impact of reforms on GDP per capita and its supply side components 5 years after the reforms

\begin{tabular}{|c|c|c|c|c|c|}
\hline \multirow{2}{*}{$\begin{array}{l}\text { Structural policy } \\
\text { areas }\end{array}$} & \multirow{2}{*}{$\begin{array}{l}\text { Size of a } \\
\text { typically } \\
\text { observed }\end{array}$} & \multirow{2}{*}{$\begin{array}{c}\text { Total effect } \\
\text { on GDP per } \\
\text { capita }\end{array}$} & \multicolumn{3}{|c|}{ Impact on supply side components } \\
\hline & & & MFP & $\mathbf{K} / \mathbf{Y}$ & $\mathbf{L} / \mathbf{N}$ \\
\hline & & in percent & \multicolumn{2}{|c|}{ in percent } & $\begin{array}{l}\text { in percentage } \\
\text { points }\end{array}$ \\
\hline Product market regulation & & $0.72 \%$ & & & \\
\hline ETCR (0-6, 6 is strictest) & -0.31 & $0.72 \%$ & $0.53 \%$ & $0.07 \%$ & 0.10 \\
\hline \multicolumn{2}{|c|}{ Intermediate policy channels mainly affecting } & $0.87 \%$ & & & \\
\hline Openness & 4.01 & $0.79 \%$ & $0.79 \%$ & & \\
\hline R\&D (business exp.) & 0.10 & $0.09 \%$ & $0.09 \%$ & & \\
\hline \multicolumn{2}{|l|}{ Investment specific policies } & $0.28 \%$ & & & \\
\hline Corporate tax & -0.98 & $0.28 \%$ & & $0.57 \%$ & \\
\hline \multicolumn{2}{|l|}{ Labour market policies } & $2.88 \%$ & & & \\
\hline \multicolumn{2}{|l|}{ Labour market regulations } & $0.22 \%$ & & & \\
\hline EPL (regular contr., 0-6, 6 is strictest) & -0.30 & $0.22 \%$ & & $0.24 \%$ & 0.07 \\
\hline \multicolumn{2}{|l|}{ Tax-benefit and activation policies } & $1.39 \%$ & & & \\
\hline Unemployment benefits & -1.42 & $0.31 \%$ & & & 0.21 \\
\hline ALMP spending & 3.18 & $0.46 \%$ & $0.09 \%$ & & 0.25 \\
\hline Tax wedge & -2.28 & $0.36 \%$ & & & 0.24 \\
\hline Tax wedge (single) & -1.39 & $0.25 \%$ & & & 0.17 \\
\hline \multicolumn{2}{|l|}{ Wage setting institutions } & $0.58 \%$ & & & \\
\hline Excess coverage & -1.89 & $0.09 \%$ & & & 0.06 \\
\hline Minimum wage & -2.48 & $0.49 \%$ & & & 0.32 \\
\hline \multicolumn{2}{|l|}{ Labour market policies for } & $0.69 \%$ & & & \\
\hline Family benefits in kind & 0.11 & $0.17 \%$ & & & 0.11 \\
\hline Maternity leave weeks & 4.83 & $0.42 \%$ & & & 0.28 \\
\hline Legal retirement age & 0.57 & $0.10 \%$ & & & 0.06 \\
\hline
\end{tabular}

Note: Typically observed reforms are measured here by the average of all beneficial two-year policy changes that were observed over two consecutive years in the sample. The total GDP/capita effect uses the employment effects from the aggregation across demographic groups, and it uses the formula in eq. (5) to aggregate across supply side components. 
Table 4. The impact of reforms on GDP per capita at different horizons

\begin{tabular}{|c|c|c|c|c|}
\hline \multirow[t]{2}{*}{$\begin{array}{l}\text { Structural policy } \\
\text { areas }\end{array}$} & \multirow{2}{*}{$\begin{array}{l}\text { Size of a typically } \\
\text { observed reform }\end{array}$} & \multicolumn{3}{|c|}{ Total effect on GDP per capita } \\
\hline & & After 5 years & After 10 years & $\begin{array}{l}\text { After full convergence } \\
\text { (long run) }\end{array}$ \\
\hline Product market regulation & & $0.72 \%$ & $1.02 \%$ & $2.09 \%$ \\
\hline $\operatorname{ETCR}(0-6,6$ is strictest) & -0.31 & $0.72 \%$ & $1.02 \%$ & $2.09 \%$ \\
\hline \multicolumn{2}{|c|}{ Intermediate policy channels mainly affecting productivity } & $0.87 \%$ & $1.34 \%$ & $2.86 \%$ \\
\hline Openness (perc. of GDP) & 4.01 & $0.79 \%$ & $1.17 \%$ & $2.40 \%$ \\
\hline$R \& D$ (business exp.) (perc. of GDP) & 0.10 & $0.09 \%$ & $0.17 \%$ & $0.46 \%$ \\
\hline Investment specific policies & & $0.28 \%$ & $0.38 \%$ & $1.25 \%$ \\
\hline Corporate tax (as perc. of GDP) & -0.98 & $0.28 \%$ & $0.38 \%$ & $1.25 \%$ \\
\hline Labour market policies & & $2.88 \%$ & $4.03 \%$ & $5.78 \%$ \\
\hline Labour market regulations & & $0.22 \%$ & $0.57 \%$ & $1.83 \%$ \\
\hline EPL (regular contr., $0-6,6$ is strictest) & -0.30 & $0.22 \%$ & $0.57 \%$ & $1.83 \%$ \\
\hline Tax-benefit and activation policies & & $1.39 \%$ & $1.74 \%$ & $2.10 \%$ \\
\hline Unemployment benefits (perc. of earnings) & -1.42 & $0.31 \%$ & $0.42 \%$ & $0.45 \%$ \\
\hline $\begin{array}{l}\text { ALMP spending (per unemployed, as perc. of } \\
\text { GDP/capita) }\end{array}$ & 3.18 & $0.46 \%$ & $0.57 \%$ & $0.85 \%$ \\
\hline Tax wedge (perc.points) & -2.28 & $0.36 \%$ & $0.45 \%$ & $0.47 \%$ \\
\hline Tax wedge (single) (perc.points) & -1.39 & $0.25 \%$ & $0.31 \%$ & $0.32 \%$ \\
\hline Wage setting institutions & & $0.58 \%$ & $0.79 \%$ & $0.86 \%$ \\
\hline Excess coverage (perc.points) & -1.89 & $0.09 \%$ & $0.14 \%$ & $0.15 \%$ \\
\hline Minimum wage (perc. of median) & -2.48 & $0.49 \%$ & $0.66 \%$ & $0.70 \%$ \\
\hline Labour market policies for & & $0.69 \%$ & $0.92 \%$ & $0.99 \%$ \\
\hline Family benefits in kind (perc. of GDP) & 0.11 & $0.17 \%$ & $0.23 \%$ & $0.24 \%$ \\
\hline Maternity leave weeks & 4.83 & $0.42 \%$ & $0.57 \%$ & $0.61 \%$ \\
\hline Legal retirement age & 0.57 & $0.10 \%$ & $0.13 \%$ & $0.14 \%$ \\
\hline
\end{tabular}

Note: Typically observed reforms are measured here by the average of all beneficial two-year policy changes that were observed over two consecutive years in the sample. The total GDP/capita effect uses the employment effects from the aggregation across demographic groups, and it uses the formula in eq. (5) to aggregate across supply side components. 
Figure 3. Effects of improving structural policy areas: details by supply side components after 5 and 10 years

Predicted effects of typically observed reforms* in each policy area

MFP

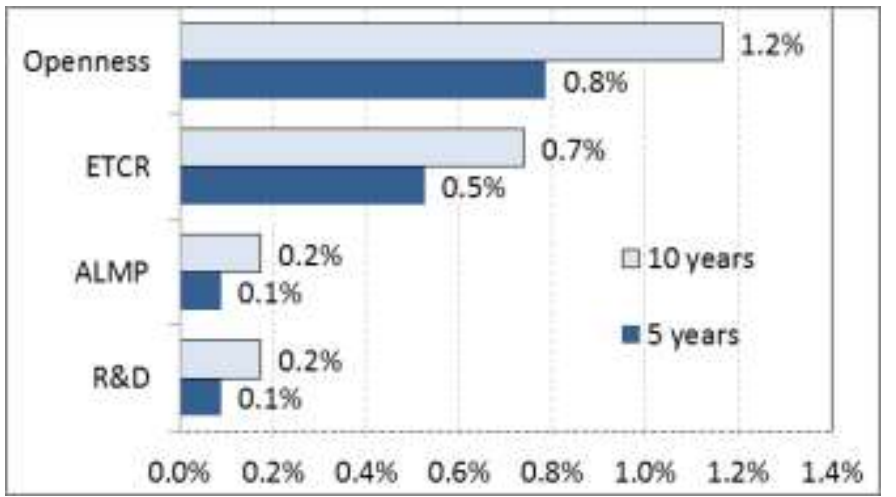

Capital intensity $(\mathrm{K} / \mathrm{Y})$

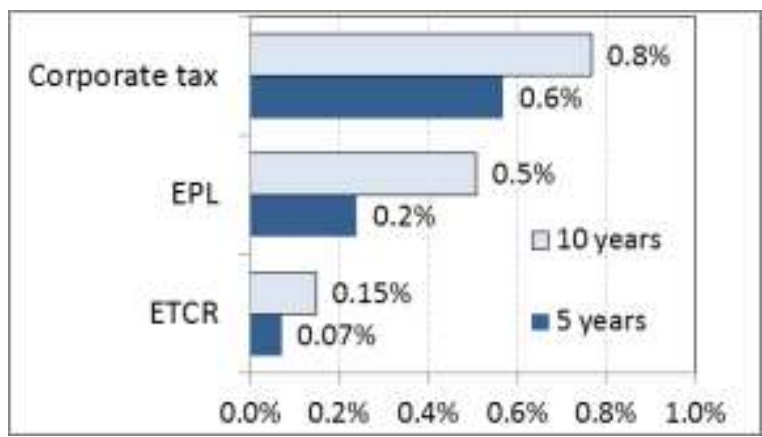

Employment rate $(\mathrm{L} / \mathrm{N})$

(in percentage points, showing three different aggregations)

After 5 years

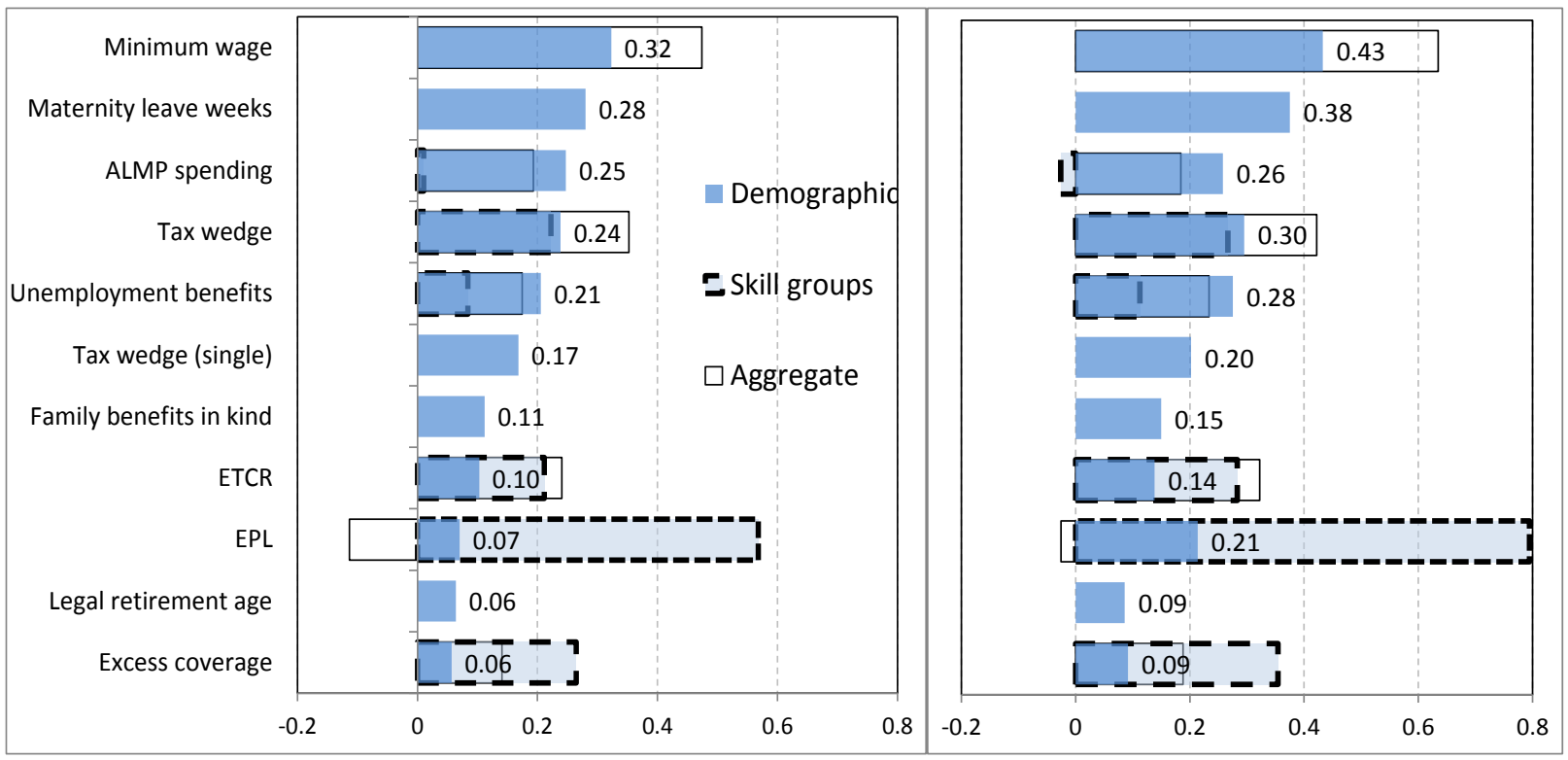

Note: *Typically observed reforms are measured as the average improvements in the policy indicators over all two year windows that show improvements in both periods (see Table 5, column 4). The employment rate effects use all three aggregation approaches, and the size of the effects is indicated by numbers for the aggregation using demographic groups.

\subsubsection{Country-specific effects in the new framework}

26. The new simulation framework allows for country heterogeneities in three different ways:

- Heterogeneous effects through different reform intensity (see Table A5.1 in Appendix 5)

- Heterogeneous effects through the interaction of wage setting institutions. The effect of labour tax wedge is found to depend on the level of excess coverage of wage bargaining (Gal and Theising, 2015, and de Serres, Hijzen and Murtin, 2014). The payoffs from lowering the average labour tax wedge can be substantially higher for countries with higher excess coverage. The gains 
in the employment rate from a cut in the labour tax wedge (a reduction corresponding to the average observed over two consecutive years) are by 0.4 percentage point larger for a country with a high excess coverage than for one where it is low (Figure 4).

- Heterogeneous effects through differences in the age, gender and skill composition of the population. In principle, they can be another source of country-specificity in the framework, as the labour market results show heterogeneities across these groups. However, these effects are rather small in practice. For instance, using the lowest and the highest shares of the most responsive groups to policies (i.e. youth or low educated) makes only a marginal difference $(0.1$ to 0.2 percentage point) for the final impact on aggregate employment (these results are not reported here). Hence in practice, differences in the relative size of these demographic groups, as well as in the skill composition of countries have only limited effects on per capita income. This serves as one more motivation to expand the framework with more non-linear effects and interactions between policy areas.

Figure 4. Employment effects of tax wedge reforms in a low vs. high excess coverage country

Predicted effects of typically observed reforms* in each policy area

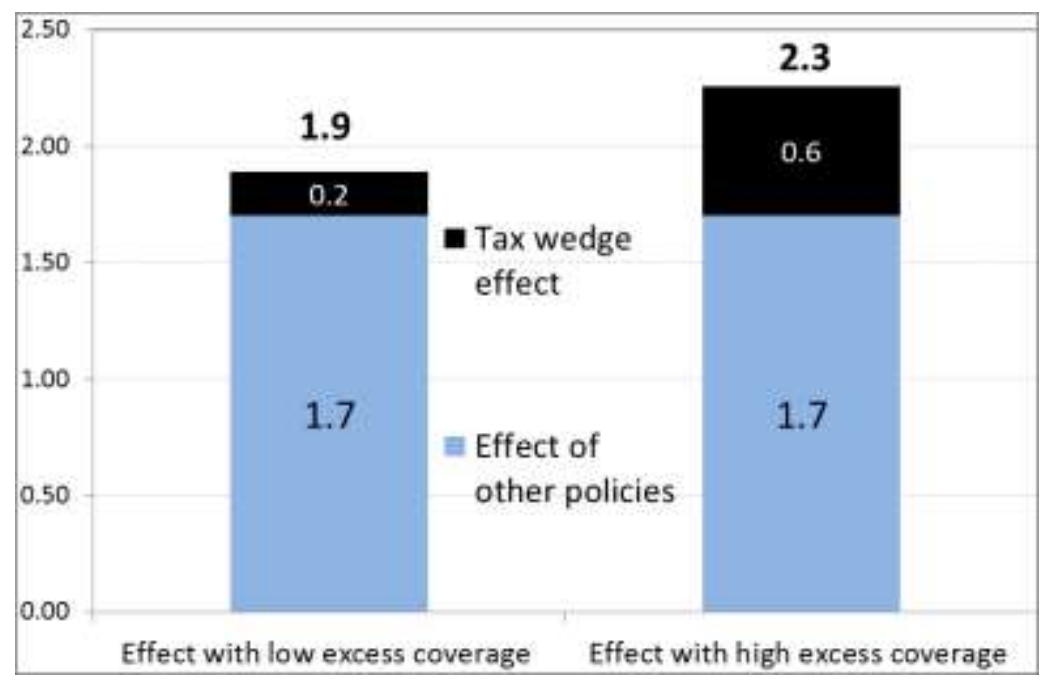

Note: *Typically observed reforms are measured as the average improvements in the policy indicators over all two year windows that show improvements in both periods (see Table 5, column 2). The low and high excess coverage country corresponds to the $25^{\text {th }}$ and $75^{\text {th }}$ percentile of the excess coverage distribution in 2011 (Poland and Greece, respectively).

\section{Conclusion}

27. This document describes and discusses a new simulation framework that quantifies the impact of structural reforms on per capita income. Comparted to earlier attempts, the new framework developed in this paper broadens the range of quantifiable reforms, updates the underlying empirical relationships, covers the post-crisis period and improves the framework's internal consistency. The document presents the new coefficient estimates on the three main supply-side components (MFP, capital and employment). The paper is a step in a gradual, ongoing process to continuously improve and update the quantification of the effect of structural reforms on per capita income levels. Further work is needed to better account for country-specific effects and to extend the analysis to emerging market economies. Last but not least, the extent to which the macroeconomic estimates are consistent with results obtained on the basis of sectorand firm-level data will be verified in future work.

28. Using typical past reforms as a basis for simulation, the new framework provides a number of results for the main policy variables. First, five years after the reforms, product market regulation has the 
largest overall single policy impact. However, the combined impact of all labour market policies is considerably larger than that of product market regulation and the remaining policies combined (corporate taxes and R\&D spending). Some specific policies have only a minor impact on per capita income levels. They include the legal retirement age and business spending on R\&D.

29. Second, policy impacts can differ at different horizons. For some policies, the overall long-term effects on GDP per capita can be considerably larger than the 5- to 10-year impacts. This is particularly the case of policies that influence GDP per capita through capital deepening (product market regulation, employment protection legislation and spending on active labour market policies). The long-term impact of other policies, mostly labour market policies transiting only via the employment rate channel, materialises at shorter horizon.

30. Third, the new framework shows the determinants of policies through the separate supply-side channels:

31. Fourth, different policies have different impacts on the separate supply-side channels. For instance, corporate taxes have a much larger impact on investment compared to product market regulations. The impact of legal retirement age on the employment rate is roughly 5 times smaller than those found for minimum wages, maternity leave weeks or ALMP spending.

32. Finally, there is no robustly significant relationship between employment protection legislation reform on the aggregate employment rate. Some policy areas (family benefits, pension age) can be assessed and included in the framework only by demographic groups. Hence as a benchmark in future quantification exercises, the effects found when aggregating across demographic groups could be used. 


\section{REFERENCES}

Adalet-McGowan, M. and D. Andrews (2015), "Labour Market Mismatch and Labour Productivity: Evidence from PIAAC Data”, OECD Economics Department Working Papers No. 1209.

Addison, J.T. and O.D. Ozturk (2012), "Minimum Wages, Labor Market Institutions and Female Employment: A Cross-Country Analysis", Industrial and Labor RelationsReview, 65(4), 779-809

Autor, D. H., W. R. Kerr and A. D. Kugler (2007), "Does employment protection reduce productivity? Evidence from US States", Economic Journal, 117(521), 189-217.

Barnes, S., R. Bouis, P. Briard, S. Dougherty and M. Eris (2013), "The GDP impact of reform: a simple simulation framework", OECD Economics Department Working Papers No. 834.

Bassanini, A. and R. Duval (2006), "Employment Patterns in OECD countries: Reassessing the Role of Policies and Institutions", OECD Social, Employment and Migration Working Papers No. 35.

Bassanini, A., L. Nunziata, and D. Venn (2009), "Job Protection Legislation and Productivity Growth in OECD Countries”, Economic Policy, Vol. 24(58), pp. 249-402.

Bouis, R and R. Duval (2011), "Raising potential growth after the crisis", OECD Economics Department Working Papers No. 835.

Bouis R., R. Duval and F. Murtin (2011), "The policy and institutional drivers of economic growth across OECD and non-OECD economies: New evidence from growth regressions", OECD Economics Department Working Papers No. 843.

Cette, G., J. Lopez and J. Mairesse (2013), "Upstream product market regulations, ICT, R\&D and productivity”, NBER Working Papers No. 19488.

Cette, G., J. Lopez and J. Mairesse (2013), "Product and labour market regulations, production prices, wages and productivity", NBER Working Papers No.20563.

Cingano, F., M. Leonardi, J. Messina and G. Pica (2010), The effect of employment protection legislation and financial market imperfections on investment: evidence from a firm-level panel of EU countries, Economic Policy, 25(61), 117-63.

Cingano, F., M. Leonardi, J. Messina and G. Pica (2015), Employment protection legislation, capital investment and access to credit: evidence from Italy, Economic Journal, doi:10.1111/ecoj.12212

Dougherty, S., V.C. Frisancho Robles and K. Krishna (2011), "Employment protection legislation and plant-level productivity in India", NBER Working Paper Series No. 17693.

Égert, B. (2016a), "Regulation, institutions and productivity: new macroeconomic evidence from OECD countries", OECD Economics Department Working Paper (forthcoming)

Égert, B. (2016b), "Regulation, institutions and aggregate investment: new evidence from OECD countries", OECD Economics Department Working Paper (forthcoming). 
Égert, B. and P. Gal (2016), “The quantification of structural reforms: introducing country-specific policy effects", OECD Economics Department, mimeo.

Engle, R.F. and C.W.J. Granger (1987), "Co-integration and error correction: representation, estimation and testing", Econometrica, Vol. 55(2), pp. 251-276.

Gal, P. and A. Theising (2015), "The macroeconomic impact of policies on labor market outcomes in OECD countries: a reassessment”, OECD Economics Department Working Paper No. 1271.

Hendry, D.F. (1986),"Econometric modelling with cointegrated variables: an overview ", Oxford Bulletin of Economics and Statistics, Vol. 48(3), pp. 201-212.

Jaumotte, F. (2003), "Labour Force Participation of Women: Empirical Evidence on the Role of Policy and Other Determinants in OECD Countries", OECD Economic Studies, No. 37, pp. 51-108.

Johansson, A., Y. Guillemette, F. Murtin, D. Turner, G. Nicoletti, C. de la Maisonneuve, P. Bagnoli, G. Bousquet and F. Spinelli (2013), "Long-term growth scenarios", OECD Economics Department Working Papers No. 1000, OECD Publishing.

Neumark, D. (2015) “The Effects of Minimum Wages on Employment”, Federal Reserve Bank of San Francisco Economic Letter, 2015-37

Nickell, S. (1981). "Biases in Dynamic Models with Fixed Effects", Econometrica, Vol. 49(6), pp. 14171426.

OECD (2015a), “Quantification of structural reforms”, ECO/CPE/WP1/2015(5).

OECD (2015b), OECD Employment Outlook, OECD Publishing, Paris.

Phillips, P.C.B. and B.E. Hansen (1990), "Statistical inference in instrumental variables regression with I(1) processes", The Review of Economic Studies, Vol. 57(1), 99-125.

Rincon-Aznar, A. and W.S. Siebert (2012), "Employment production, productivity, wages and jobs in Europe", INDICSER Discussion Paper No. 36.

De Serres, A., A. Hijzen and F. Murtin (2014), "Unemployment and the Coverage Extension of Collective Wage Agreements", European Economic Review, Vol. 71, pp. 52-66.

Stock, J. and M. W. Watson (1993), "A simple estimator of co-integrating vectors in higher order integrated systems", Econometrica, Vol. 61(4), pp. 783-820. 


\section{APPENDIX 1. COMPARISON OF THE OLD AND NEW FRAMEWORKS}

1. The previous frameworks used in ECO are grounded on a production function approach (Barnes et al., 2013; Bouis and Duval, 2011; Johansson et al., 2013). The influence of policies on GDP is typically assessed through their impact on its supply side components: labour productivity and employment. Each in turn can be further decomposed, into capital intensity and multi-factor productivity, and labour force participation and unemployment (Figure 1). Within this framework, the impact of policies on these components is obtained from a range of cross-country reduced-form panel regressions. The overall impact on GDP per capita is obtained by aggregating the policy effects of the various channels.

Figure A1,1. Channels of transmission to per capita GDP

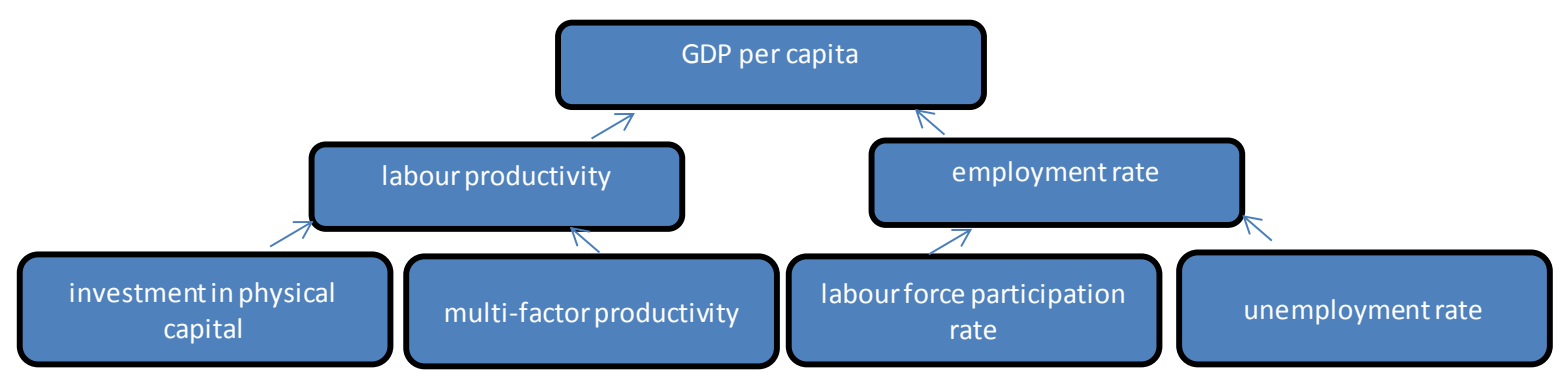

\section{More policy channels}

2. The quantification framework that has been used so far in ECO is compared here with the new framework. ${ }^{17}$ The first major difference is the number of policy determinants included in the analysis. Looking first at the three supply side components separately, the main changes are as follows (Table 1):

- The impact of policies through MFP: in the old framework, the distance to the MFP frontier and the measure of innovation intensity were the most important drivers of MFP. The new framework extends the old framework by adding product market regulation, captured by the OECD's Energy, Transport and Communication Regulation (ETCR) indicator, a subset of the Product Market Regulation (PMR) indicator, and active labour market policies (ALMPs). Other labour market policies are not used as they were not found to have a robust relation to MFP in the empirical work.

- The impact of policies on the capital stock: the old framework did not incorporate explicitly any policy drivers of capital deepening. ${ }^{18}$ The new framework integrates product market regulation (ETCR), labour market regulation captured by the employment protection legislation (EPL) indicator and a measure of corporate taxation.

17. Figures A1.2, A1.3 and A1.4 in the appendix show the structure of the quantification framework used in Bouis and Duval (2011), Barnes et al (2012) and Johansson et al. (2013).

18. The effects of PMR were estimated in some papers by using labour productivity, which take into account capital deepening indirectly (Conway et al, 2006; Arnold et al, 2009; Bourles et al, 2013). 
- The impact of policies on the employment rate: the old framework considered four labour market areas: i) unemployment benefits, ii) the labour tax wedge, iii) ALMPs and iv) childcare spending. On top of these, the new framework adds a number of labour market policies such as i) EPL, ii) the length of maternity leave, iii) wage bargaining system, iv) the legal retirement age and v) the minimum wage. Childcare spending is replaced by government spending on family benefits. The new framework also includes product market regulation (ETCR).

3. There are further important differences for the employment rate. The old framework allowed policy effects to vary by demographic groups (age and gender) for selected policies. In addition to this, the new framework allows for policy effects to vary by skill levels as well. As a consequence, countries can react differently to an identical policy change depending on the age and skill composition of their populations. A drawback is that data for many countries are available either for detailed age and gender groups or separately for different skill levels, but not for both at the same time. Hence the two approaches cannot be fully combined but can provide complementary assessments.

Table A1.1 Comparing the old and the new frameworks for quantification

\begin{tabular}{|c|c|c|c|c|}
\hline Supply-side components & Broad structural policy areas & Policies & $\begin{array}{c}\text { Old } \\
\text { framework }\end{array}$ & $\begin{array}{c}\text { New } \\
\text { framework }\end{array}$ \\
\hline \multirow{3}{*}{ Multi-factor productivity } & Product market regulation & ETCR & $\mathrm{X}$ & $\mathrm{X}$ \\
\hline & Labour market policies & ALMP & & $\mathrm{X}$ \\
\hline & Intermediate outcomes & $\begin{array}{l}\text { innovation intensity }(\mathrm{R} \& \mathrm{D}) * \\
\text { trade openness* }\end{array}$ & $\mathrm{X}$ & $\begin{array}{l}X \\
X\end{array}$ \\
\hline \multirow{3}{*}{ Capital deepening } & Product market regulation & ETCR & & $\mathrm{X}$ \\
\hline & Labour market policies & EPL & & $\mathrm{X}$ \\
\hline & Investment specific policies & corporate tax rate & & $\mathrm{X}$ \\
\hline \multirow{6}{*}{ Employment rate } & Product market regulation & ETCR & & $\mathrm{X}$ \\
\hline & Labour market policies & & & \\
\hline & Labour market regulations & EPL & & $\mathrm{X}$ \\
\hline & $\begin{array}{l}\text { Tax-benefit and activation } \\
\text { system }\end{array}$ & $\begin{array}{l}\text { ALMP } \\
\text { unemployment benefits } \\
\text { labour tax wedge }\end{array}$ & $\begin{array}{l}X \\
X \\
X\end{array}$ & $\begin{array}{l}X \\
X \\
X\end{array}$ \\
\hline & Wage setting institutions & $\begin{array}{l}\text { minimum wage } \\
\text { wage bargaining (excess } \\
\text { coverage/union density) }\end{array}$ & & $\begin{array}{l}X \\
X\end{array}$ \\
\hline & $\begin{array}{l}\text { Policies for specific } \\
\text { demographic groups }\end{array}$ & $\begin{array}{l}\text { childcare spending } \\
\text { family benefit spending } \\
\text { maternity leave length } \\
\text { pension system } \\
\end{array}$ & $\mathrm{X}$ & $\begin{array}{l}X \\
X \\
X \\
\end{array}$ \\
\hline Labour productivity & & $\begin{array}{l}\text { EPL } \\
\text { tax structure }\end{array}$ & $\begin{array}{l}X \\
X\end{array}$ & \\
\hline
\end{tabular}

Note: * denotes policy channels that are intermediate outcomes rather than policies per se and are used as a shortcut to capture policy changes in these areas. For a more accurate evaluation, further empirical analysis is needed to establish a quantitative link between these outcomes and policies.

\section{Updating and improving internal consistency}

4. Internal consistency is improved in three ways. First, supply-side channels are used in a consistent manner: different levels of disaggregation of the supply side components are not mixed across policy areas (e.g. employment for some policies, the labour force participation and unemployment rate for others). Second, econometric estimates are obtained using the very same up-dated dataset and estimation technique. Third, changes in policy measures and the horizons at which their impact is measured are standardised. 


\section{Consistent use of supply-side channels}

5. The new framework uses consistently the supply-side components through which policy effects are channelled into per capita income. The old framework includes labour productivity for some policies and capital deepening and multi-factor productivity (MFP) for others. It also contains the employment rate for certain policies, but uses its subcomponents (labour force participation or the unemployment rate) for others.

6. The new framework systematically looks at MFP and capital deepening (but not at labour productivity). Policy effects on the employment rate are derived from direct estimates of policies on the employment rate and not through an aggregation of policy effects on its components, the unemployment and labour force participation rates. The main reason for this is to ensure that a consistent overall employment rate effect is obtained. Many policies (such as unemployment benefits through discouragement effects) can have an impact on both the unemployment rate and the labour force participation rate, in particular over the medium-to long run (for recent evidence, see Gal and Theising, 2015, Table 8). But the two separate channels cannot be simply aggregated to arrive at overall employment rate effects, because the unemployment rate can change mechanically if the participation rate changes (it is calculated as the number of unemployed over labour force participation). Overall, for the medium-to long run policy effects that are the key focus in the framework, the benefits in terms of policy channels from splitting into labour force participation and unemployment are limited and raises issues of arriving at consistent employment rate effects. ${ }^{19}$

\section{Coefficient estimates based on the very same dataset and estimation techniques}

7. Internal consistency is also largely enhanced by estimating the policy effects on the very same dataset (SPIDER, see below) and using the same estimation technique (Table 2). By contrast, the old framework uses empirical estimates from several previous studies:

- The impact of product market regulation on economy-wide MFP (through a reduction in the gap to the frontier) was calculated using panel estimates on sectoral data from Bourlès et al. (2013). The effects of R\&D on MFP were borrowed from de Serres, Yashiro and Boulhol. (2014).

- The impact of labour market policies on the employment and unemployment rates was assessed based on coefficient estimates reported in Bassanini and Duval (2006). These results were further complemented with coefficient estimates from a labour market study on female participation (Jaumotte, 2003) and on employment protection (Bassanini et al, 2009).

19. Separate, targeted analyses can be used to assess the policy impacts on the unemployment and participation rate. For instance, using labour market statuses (unemployment, employment and inactive) and the flows across them, see recent work using individual level data by Garda (2016). 
Table A1.2 Main characteristics of the old and new frameworks for quantification

\begin{tabular}{|c|c|c|c|c|c|c|}
\hline Supply-side components & $\begin{array}{c}\text { Structural } \\
\text { policy channels }\end{array}$ & Study & Data & $\begin{array}{l}\text { Estimation } \\
\text { technique }\end{array}$ & $\begin{array}{l}\text { Number of } \\
\text { countries }\end{array}$ & $\begin{array}{c}\text { Time } \\
\text { period }\end{array}$ \\
\hline \multicolumn{7}{|c|}{ Old framework } \\
\hline \multirow{2}{*}{ Multi-factor productivity } & $\begin{array}{l}\text { innovation } \\
\text { intensity (R\&D) }\end{array}$ & $\begin{array}{c}\text { De Serres et al } \\
\text { (2014) }\end{array}$ & Country level & OLS & 20 & $1980-2010$ \\
\hline & $\begin{array}{l}\text { product market } \\
\text { regulation }\end{array}$ & $\begin{array}{l}\text { Bourlès et al. } \\
\text { (2013) }\end{array}$ & Sector level & (restricted) ECM & 15 & $1985-2007$ \\
\hline \multirow[t]{2}{*}{ Labour market outcomes } & $\begin{array}{l}\text { unemployment } \\
\text { benefits } \\
\text { tax wedge } \\
\text { ALMP }\end{array}$ & $\begin{array}{l}\text { Bassanini and } \\
\text { Duval (2006) }\end{array}$ & \multirow[t]{2}{*}{ Country level } & $\begin{array}{l}\text { OLS } \\
\text { SUR } \\
\text { OLS }\end{array}$ & 20 & $1982-2003$ \\
\hline & childcare spending & Jaumotte (2003) & & 2SLS & 17 & $1985-1999$ \\
\hline \multirow[t]{2}{*}{ Labour productivity } & EPL & $\begin{array}{c}\text { Bassanini et al. } \\
\text { (2009) }\end{array}$ & & $\mathrm{ECM}$ & 11 & $1982-2003$ \\
\hline & tax structure & Arnold (2008) & Country level & Pooled mean group & 21 & 1971-2004 \\
\hline \multicolumn{7}{|c|}{ New framework } \\
\hline Multi-factor productivity & \multirow{3}{*}{\multicolumn{2}{|c|}{ see Table A 1.1}} & \multirow{3}{*}{ Country level } & \multirow{3}{*}{ DOLS, two-step ECM } & $25-34$ & $1985-2011$ \\
\hline Capital deepening & & & & & $25-31$ & $1985-2011$ \\
\hline Employment rate & & & & & 25 & $1985-2011$ \\
\hline
\end{tabular}

References used in the table:

Arnold, J. (2008), "Do Tax Structures Affect Aggregate Economic Growth? Empirical Evidence from a Panel of OECD Countries”, OECD Economics Department Working Papers, No. 643.

Bassanini, A. and R. Duval (2006), "Employment Patterns in OECD Countries: Reassessing the Role of Policies and Institutions", OECD Economics Department Working Paper, No. 486.

Bassanini, A., L. Nunziata, and D. Venn (2009), "Job Protection Legislation and Productivity Growth in OECD Countries", Economic Policy, Vol. 24, No. 58.

Bourlès, R., G. Cette, J. Lopez, J. Mairesse and G. Nicoletti (2013). "Do Product Market Regulations In Upstream Sectors Curb Productivity Growth? Panel Data Evidence For OECD Countries," The Review of Economics and Statistics, MIT Press, vol. 95(5), pages 1750-1768, December.

De Serres, A., N. Yashiro and H. Boulhol (2014) "An International Perspective on the New Zealand Productivity Paradox", New Zealand Productivity Commission Working Paper 2014/01

Jaumotte, F. (2004), "Labour Force Participation of Women: Empirical Evidence on the Role of Policy and Other Determinants in OECD Countries”, OECD Economic Studies, No. 37.

\section{The SPIDER database}

8. The first pillar of internal consistency is the database dubbed Structural Policy Indicator Database for Economic Research (SPIDER) used for all estimations in the new framework. SPIDER contains a large number of policy and institutional indicators from nearly 50 different OECD and non-OECD sources. OECD sources include for instance the product market regulation (PMR) or the employment protection legislation (EPL) indicators. Non-OECD sources cover for instance various World Bank and IMF databases and datasets used in academic articles.

9. The database contains the original variables and their transformed versions that were used in past empirical analysis. For instance, spending on active labour market policies can be used as a share of GDP but also as average spending per unemployed (as suggested in Bassanini and Duval, 2006; De Serres and Murtin, 2013). Another example is the unemployment benefit replacement rate, which combines two versions of the same data (an earlier and a more recent) in order to extend the coverage and obtain a longer 
series. The dataset is available in an easily accessible database for standard econometric software (Stata and Eviews). It is readily available for analysis: country codes have been standardised across the various sources and tags for country groups (e.g. OECD, BRIICS) have been defined. A subset of the variables included in SPIDER will most probably be rendered public in the course of 2016.

\section{A common estimation methodology}

10. The second pillar of internal consistency is a common methodology to obtain new estimates of policy effects. The estimations rely on a standard two-step error correction model (ECM) framework, in which the long-run effects are estimated using the Dynamic OLS estimator. Such a framework pins down the long-run impact of policies on MFP, investment and labour market outcomes. It can also identify shortterm effects and the adjustment path to the long-run effect.

\section{Standardisation of changes in policies}

11. A series of simulations are performed to illustrate the magnitude of the effect of policy changes on the basis of estimated parameters. In the new framework, the reform measures used in the simulations are standardised to a large extent (Section 4 provides more details on this). The old framework assumed varying reform intensities to illustrate the economic impact of policies. The new framework provides the long-run policy effects and the adjustments path towards the long-run effects using the same methodology for each policy area (Dynamic OLS estimator imbedded in a 2-step error correction model). In contrast, the old framework relied on additional assumptions to pin down the effects prevailing over various horizons (5-years, 10-years and long-term effect after full convergence).

\section{Updating the coefficient estimates}

12. The new framework relies on updated coefficient estimates. It makes use of econometric estimates covering the post-crisis period (mostly until 2011-2013) for all three supply-side channels (MFP, capital deepening and the employment rate). In contrast, the old framework employed coefficient estimates obtained on the basis of datasets that tend to run only until the mid-2000s. Also, the different coefficients were retrieved from samples covering different time periods and a different set of countries (Table 2). In the new framework, the number of OECD countries covered is at least 25, with some countries dropping out due to data availability constraints (typically Chile, Mexico and Turkey, but also Israel, Iceland and some Central and Eastern European countries) 
Detailed channels of policies on long-term growth

Figure A1.2. The framework used by Bouis and Duval (2011)

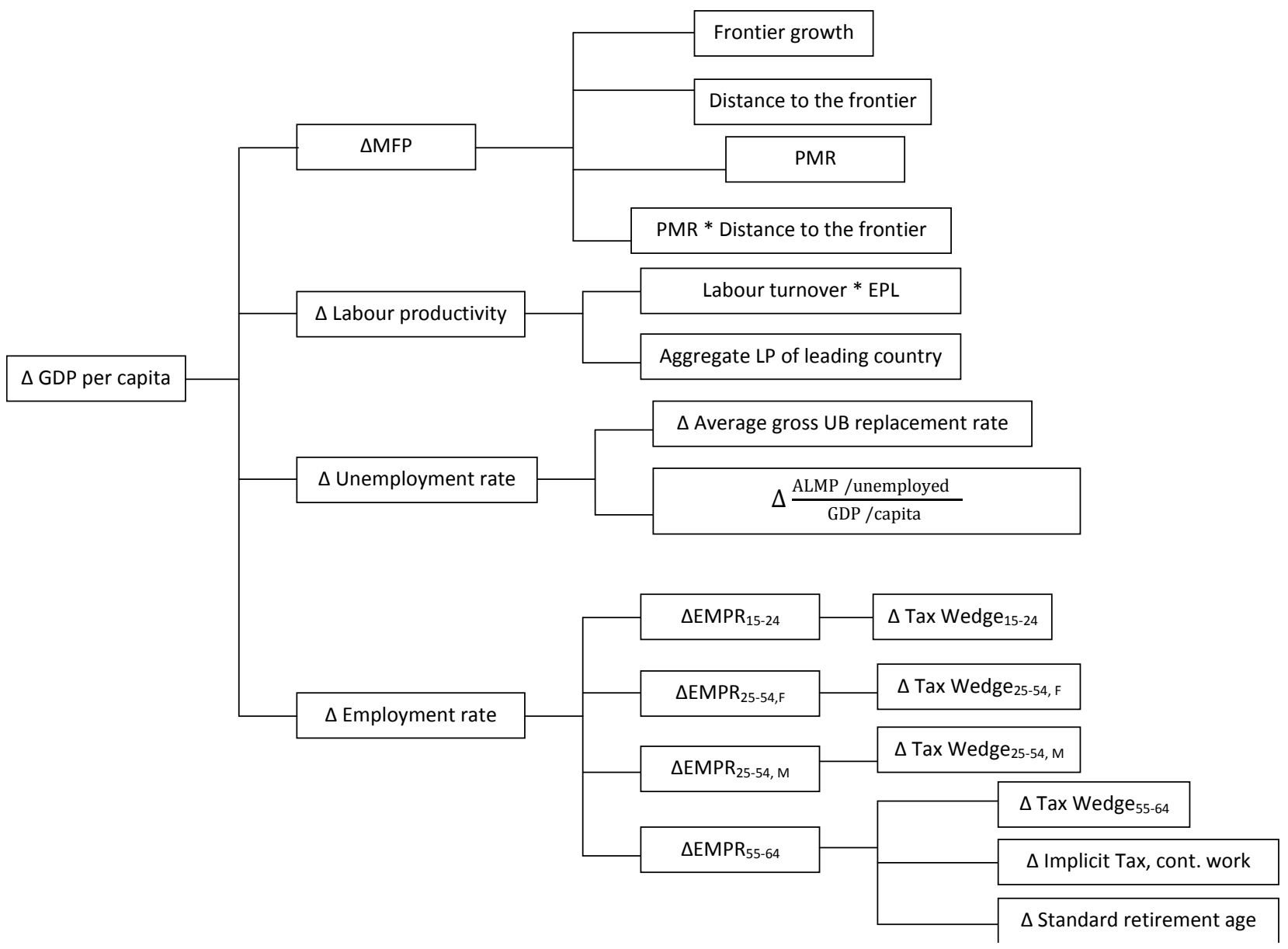


Figure A1.3. The framework used by Johansson et al (2013)

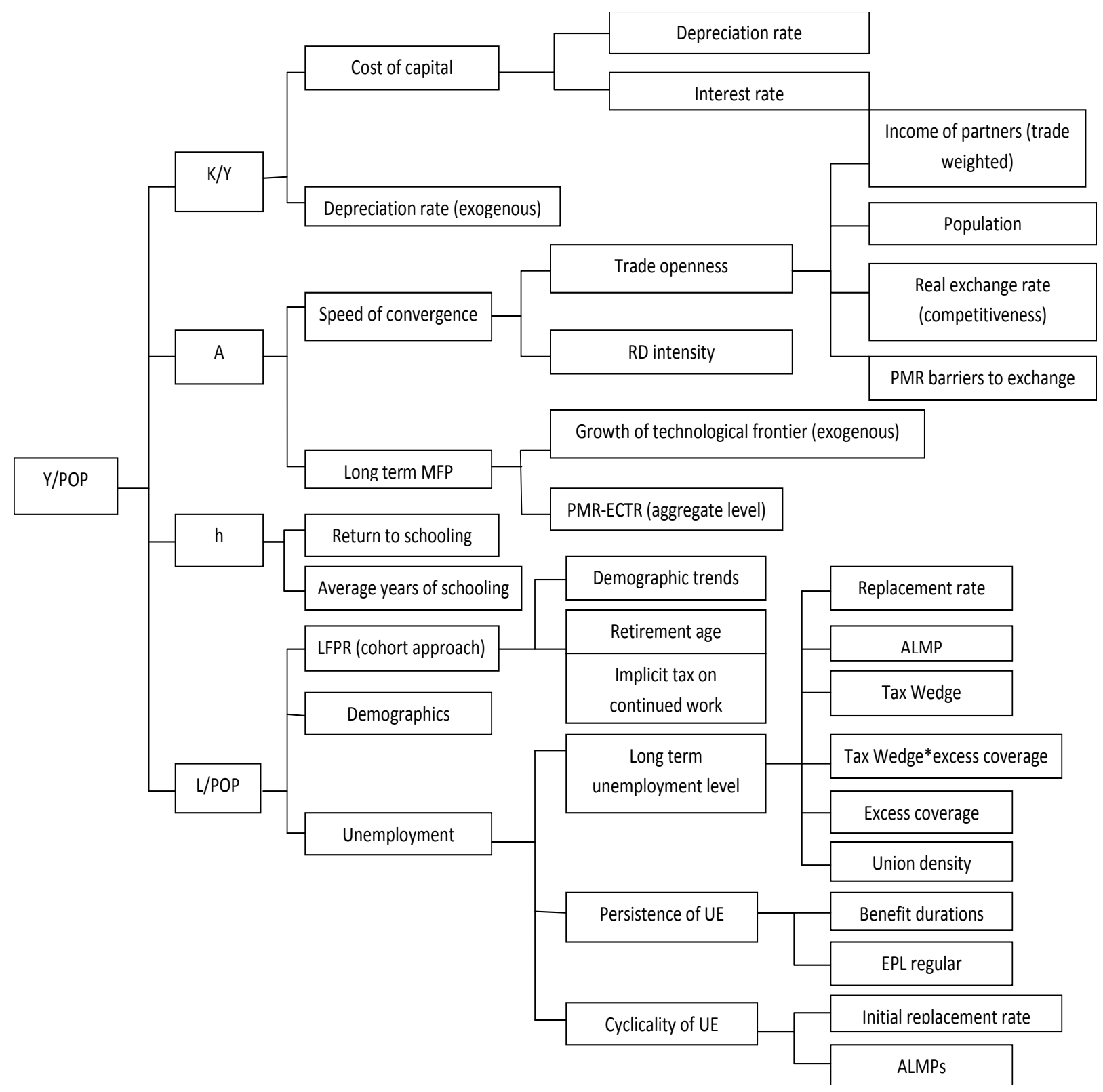


Figure A1.4. The framework used by Barnes et al. (2013)

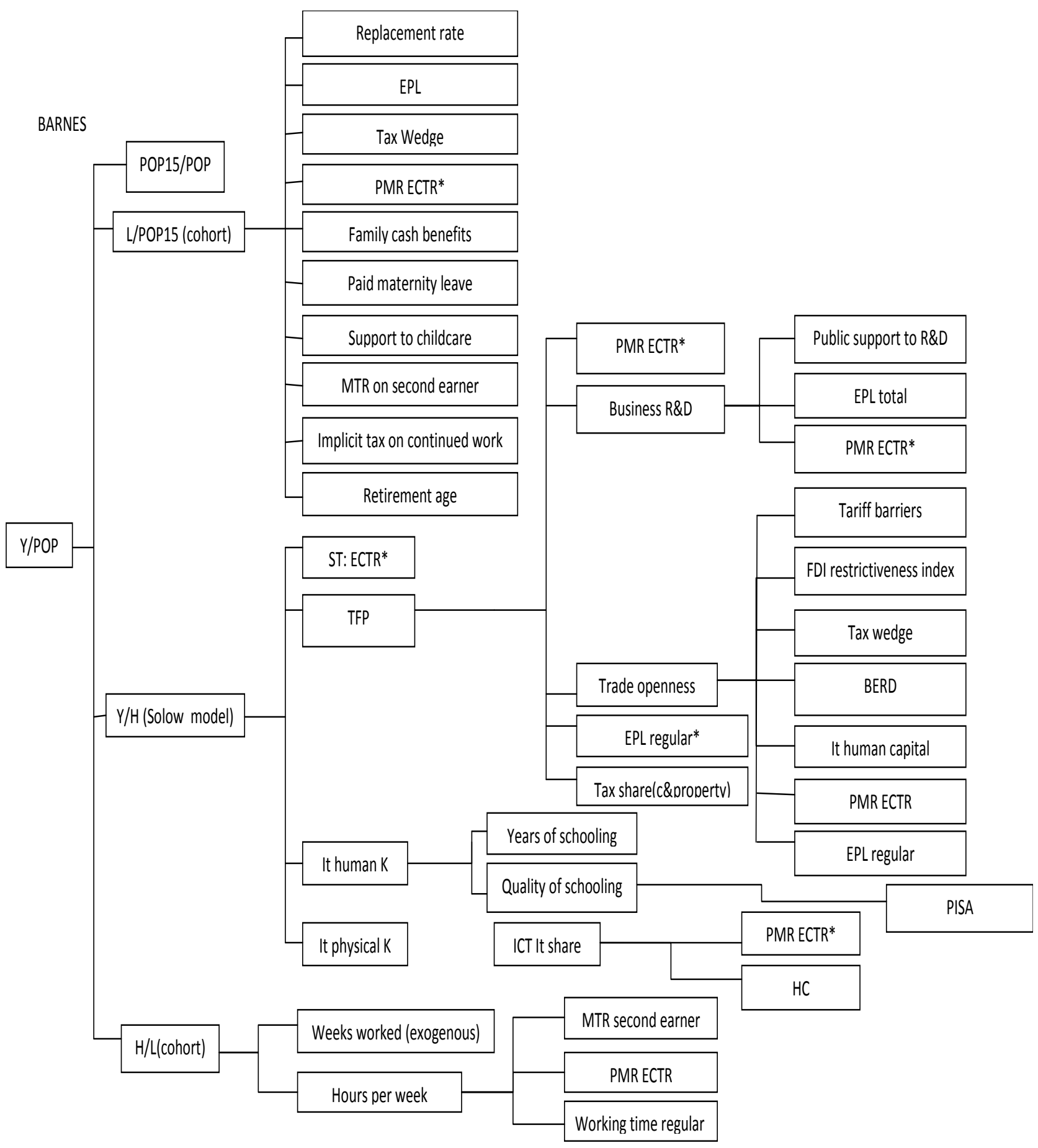




\section{APPENDIX 2. DESCRIPTIVE STATISTICS OF THE POLICY VARIABLES USED FOR THE SIMULATION}

Table A2.1 Descriptive statistics on policy variables

\begin{tabular}{|c|c|c|c|c|c|c|c|c|}
\hline & $<0^{\gamma^{2}} \partial^{\sigma^{5}}$ & $5_{0 .}$ & $p^{j e^{v^{0}}}$ & $5 e^{v^{x}}$ & $h^{j 0^{j 0^{n}}}$ & s) & jis & $s^{+}$ \\
\hline Average gross unemployment benefit rEPL (regular, & 595 & 25 & 23.80 & 28.06 & 29.16 & 13.58 & 0.35 & 65.21 \\
\hline ALPM & 626 & 25 & 25.04 & 23.14 & 17.78 & 21.72 & 2.79 & 169.16 \\
\hline Tax wedge for one-earner married couple, splicing & 654 & 25 & 26.16 & 29.86 & 30.70 & 10.03 & -1.07 & 51.19 \\
\hline Tax wedge for single person, splicing & 654 & 25 & 26.16 & 38.71 & 38.95 & 10.25 & 6.23 & 57.82 \\
\hline Excess coverage & 635 & 25 & 25.40 & 29.69 & 21.84 & 25.09 & -5.29 & 84.87 \\
\hline Regulation of regular employment contracts & 689 & 25 & 27.56 & 2.20 & 2.33 & 0.87 & 0.26 & 5.00 \\
\hline Aggregate ETCR (0-6, 6 is strictest) & 707 & 25 & 28.28 & 3.50 & 3.30 & 1.41 & 0.79 & 6.00 \\
\hline Family benefits in cash ( $\%$ of GDP) & 641 & 25 & 25.64 & 1.26 & 1.33 & 0.72 & 0.00 & 3.05 \\
\hline Family benefits in kind ( $\%$ of GDP) & 636 & 25 & 25.44 & 0.68 & 0.48 & 0.58 & 0.00 & 2.46 \\
\hline Number of weeks of maternity leave & 725 & 25 & 29.00 & 16.11 & 16.00 & 9.03 & 0.00 & 52.00 \\
\hline Legal age for pensions (total) & 717 & 25 & 28.68 & 62.58 & 62.83 & 2.93 & 55.00 & 67.00 \\
\hline Trade openness, adjusted for country size & 654 & 25 & 26.16 & 2.20 & -1.89 & 13.80 & -19.88 & 47.78 \\
\hline Business expenditures on R\&D by private sector & 670 & 25 & 26.80 & 0.96 & 0.78 & 0.65 & 0.05 & 3.07 \\
\hline Corporate tax rate (\% of GDP) & 687 & 25 & 27.48 & 2.98 & 2.70 & 1.48 & 0.30 & 12.80 \\
\hline
\end{tabular}




\section{APPENDIX 3. ESTIMATION METHODOLOGY: ERROR CORRECTION MODEL (ECM)}

1. The general form of an error correction model can be written as follows:

$$
\Delta Y_{c, t}=c+\rho \underbrace{\left(Y_{c, t-1}-\sum_{i} \beta^{i} X_{c, t-1}^{i}\right)}_{\text {Deviation from long-run relationship }}+\sum_{i} \alpha^{i} \Delta X_{c, t}^{i}+\varepsilon_{c, t}
$$

where $\Delta$ is the first-difference operator $\left(\Delta X_{t}=X_{t}-X_{t-1}\right)$ and $\varepsilon_{c, t}$ is the error term. Country and year fixed effects are added to equation (1) to capture unobserved country-specific information and common trends in a panel data setting.

2. This approach estimates the long-run $\left(\beta^{i}\right)$ and the short-run $\left(\alpha^{i}\right)$ relationship between policies $\left(X_{c t}^{i}\right)$ and the dependent variable of interest (MFP, investment or labour market outcomes) $\left(Y_{c t}\right)$ as well as the speed of adjustment $(\rho)$ to the country specific steady-state/long-run relationship. Negative and significant estimates of the adjustment parameter $\rho$ indicate that an error correction mechanism is present: whenever the outcome variable $Y_{c t}$ is below or above its long-run equilibrium value implied by the vector of policy variables, a negative adjustment parameter implies a closing of this gap.

3. To estimate the long-term relationship and the short-term dynamics, a two-stage approach is used. It is proposed by Engle and Granger (1987): the long-run relationship is estimated first and the lagged deviation from the long-run relationship $\left(Y_{c, t-1}-\sum_{i} \beta^{i} X_{c, t-1}^{i}\right)$, i.e. the lagged residual of the longrun relationship, is introduced in a first-difference model.

$$
\begin{array}{ll}
\text { First step: } & Y_{c, t}=c+\sum_{i} \beta^{i} X_{c, t}^{i}+\varepsilon_{c, t} \\
\text { Second step: } & \Delta Y_{c, t}=c+\rho \hat{\varepsilon}_{c, t-1}+\sum_{i} \alpha^{i} \Delta X_{c, t}^{i}+\gamma_{c, t}
\end{array}
$$

4. The vector of $\sum_{i} \beta^{i}$ can be estimated using several estimators: OLS, dynamic OLS (DOLS) of Stock and Watson (1993) or fully-modified OLS (FMOLS) of Phillips and Hansen (1990), the latter two accounting for endogeneity resulting from short-run policy changes and serial correlation. For instance, Cette et al $(2013,2014)$ use the DOLS estimator to obtain the long-term coefficients for the relation between outcomes and structural policies. This is the baseline approach adopted throughout the estimations underlying the new framework. 


\section{APPENDIX 4. ADDITIONAL ESTIMATION RESULTS}

Table A4.1 MFP and capital deepening- short-term dynamics

\section{Explanatory variables}

\section{Dependent variable}

\begin{tabular}{|c|c|c|c|c|c|}
\hline & \multicolumn{3}{|c|}{ Multi-factor productivity } & \multicolumn{2}{|c|}{ log(capital stock/output) } \\
\hline & (1) & (2) & (3) & (4) & (5) \\
\hline \multicolumn{6}{|l|}{ Product market regulation } \\
\hline ETCR aggregate & $-0.01^{* *}$ & & $-0.01^{* *}$ & $0.007^{* *}$ & $0.01^{\star *}$ \\
\hline ETCR public ownership & & $-0.007^{\star *}$ & & & \\
\hline \multicolumn{6}{|l|}{ Labour market policies } \\
\hline $\log$ ALMP & & & 0.011 & & \\
\hline EPL & & & & & 0.001 \\
\hline \multicolumn{6}{|l|}{ Intermediate outcomes } \\
\hline trade openness (size adjusted) & $0.001^{* *}$ & $0.001^{\star *}$ & $0.001^{* *}$ & & \\
\hline business exp. On R\&D by industry & $-0.023^{\star *}$ & $-0.023^{\star *}$ & -0.017 & & \\
\hline \multicolumn{6}{|l|}{ elements of the user cost of capita } \\
\hline log relative investment prices & & & & $-0.177^{\star *}$ & $-0.222^{\star *}$ \\
\hline long-term real interest rate & & & & $0.001^{* *}$ & $0.001^{* *}$ \\
\hline corporate taxes/GDP & & & & $-0.005^{\star *}$ & $-0.006^{\star *}$ \\
\hline adjusted R-squared & 0.692 & 0.693 & 0.708 & 0.745 & 0.737 \\
\hline Country / year fixed effects & Yes / No & Yes / Yes & Yes / No & Yes / Yes & Yes / Yes \\
\hline No. of observations / countries & 754 / 34 & 754 / 34 & 569 / 32 & $686 / 32$ & $581 / 31$ \\
\hline Years & $1985-2011$ & 1985-2012 & $1985-2013$ & $1985-2013$ & 1985-2013 \\
\hline
\end{tabular}

Note: The MFP regressions include human capital and output gap and the capital deepening regression output gap as control variables. Standard errors are heteroscedasticity robust. ${ }^{* *}$ and ${ }^{*}$ denote significance at the $5 \%$ and $10 \%$ level, respectively. 
Table A4.2 Employment rate - short run effects by demographic groups

\begin{tabular}{|c|c|c|c|c|}
\hline \multirow[t]{3}{*}{ Explanatory variables } & \multicolumn{4}{|c|}{ Dependent variable: employment rate } \\
\hline & \multirow{2}{*}{$\begin{array}{c}\text { Youth } \\
(2)\end{array}$} & \multirow{2}{*}{$\begin{array}{c}\begin{array}{c}\text { Prime age } \\
\text { women }\end{array} \\
(3)\end{array}$} & \multirow{2}{*}{$\begin{array}{c}\begin{array}{c}\text { Prime age } \\
\text { men }\end{array} \\
(4) \\
\end{array}$} & \multirow{2}{*}{$\begin{array}{c}\text { Elderly } \\
(5)\end{array}$} \\
\hline & & & & \\
\hline \multicolumn{5}{|l|}{ Tax-benefit and activation } \\
\hline UE benefit replacement rate & 0.091 & -0.024 & -0.027 & 0.006 \\
\hline $\begin{array}{l}\text { ALMP spending on unemployed, } \\
\text { as \% of GDP/capita (HP-trend) }\end{array}$ & $0.157^{\star \star}$ & $0.055^{\star *}$ & $0.073^{\star *}$ & 0.021 \\
\hline Tax wedge (single, no ch.) & $-0.279^{\star \star}$ & & & \\
\hline Tax wedge (couple, 2 ch.) & & -0.042 & $-0.099^{* *}$ & -0.020 \\
\hline \multicolumn{5}{|l|}{ Wage setting institutions } \\
\hline Excess coverage & $0.138^{* *}$ & 0.019 & 0.020 & 0.027 \\
\hline $\begin{array}{l}\text { Excess coverage * Tax wedge } \\
\text { (single, no ch.) }\end{array}$ & $-0.865^{\star *}$ & & & \\
\hline Excess coverage ${ }^{*}$ Tax wedge & & 0.082 & -0.064 & $0.325^{\star}$ \\
\hline Minimum wage (\%median) & -0.070 & -0.042 & 0.072 & -0.052 \\
\hline \multicolumn{5}{|l|}{ Labour and product market } \\
\hline EPL regular contracts & $1.690^{* *}$ & $0.613^{* *}$ & $0.899^{\star *}$ & $2.172^{\star \star}$ \\
\hline ETC regulation & 0.077 & -0.382 & 0.020 & 0.245 \\
\hline \multicolumn{5}{|l|}{ Policies primarily affecting } \\
\hline Family benefits in cash ( $\%$ of GDP) & & -0.062 & & \\
\hline Family benefits in kind ( $\%$ of GDP) & & 0.009 & & \\
\hline Number of weeks of maternity leave & & 0.033 & & \\
\hline \multicolumn{5}{|l|}{$\begin{array}{l}\text { Pension system - primarily } \\
\text { affecting the elderly }\end{array}$} \\
\hline Legal age for pensions (total) & & & & -0.082 \\
\hline Adjusted R-squared & .623 & .574 & .639 & .387 \\
\hline Country / year fixed effects & Yes / Yes & Yes / Yes & Yes / Yes & Yes / Yes \\
\hline No. of observations / countries & 422 / 25 & $420 / 25$ & $420 / 25$ & $422 / 25$ \\
\hline Years & $1987-2010$ & $1987-2010$ & $1987-2010$ & $1987-2010$ \\
\hline
\end{tabular}

Note: The regression is using first differences of variables and the deviation relationship reported in Table 2.. Heteroskedasticity and autocorrelation robust (Newey-West) standard errors are shown in parentheses. The regressions also include the output gap, government employment, the government budget balance, a measure of average educational attainment (adjusted mean years of schooling) and an indicator for the presence of minimum wages as further controls. See more details and Gal and Theising (2015). ** Denotes significance at the $5 \%$ and ${ }^{*}$ and the $10 \%$ level, respectively. 
ECO/WKP(2016)78

Table A4.3 Employment rate - aggregate long- and short run effects

\begin{tabular}{|c|c|c|}
\hline \multirow[t]{2}{*}{ Explanatory variables } & \multicolumn{2}{|c|}{$\begin{array}{c}\text { Dependent variable } \\
\text { employment rate }\end{array}$} \\
\hline & Long run & Short run \\
\hline \multicolumn{3}{|l|}{ Tax-benefit and activation policies } \\
\hline UE benefit replacement rate & $-0.177^{\star \star}$ & 0.022 \\
\hline $\begin{array}{l}\text { ALMP spending on unemployed, } \\
\text { as } \% \text { of GDP/capita (HP-trend) }\end{array}$ & $0.057^{* *}$ & $0.069^{* *}$ \\
\hline \multicolumn{3}{|l|}{ Tax wedge (single, no ch.) } \\
\hline Tax wedge (couple, 2 ch.) & $-0.194^{\star *}$ & $-0.064^{* *}$ \\
\hline \multicolumn{3}{|l|}{ Wage setting institutions } \\
\hline Excess coverage & $-0.107^{* *}$ & 0.019 \\
\hline \multicolumn{3}{|l|}{ Excess coverage ${ }^{*}$ Tax wedge (single, no ch.) } \\
\hline Excess coverage * Tax wedge (couple, 2 ch.) & $-0.763^{\star *}$ & -0.075 \\
\hline Minimum wage (\%median) & $-0.275^{\star \star}$ & -0.028 \\
\hline \multicolumn{3}{|l|}{ Labour and product market regulations } \\
\hline EPL regular contracts & -0.716 & $1.261^{\star *}$ \\
\hline ETC regulation & $-1.127^{\star \star}$ & -0.201 \\
\hline \multicolumn{3}{|l|}{ Policies primarily affecting women } \\
\hline \multicolumn{3}{|l|}{ Family benefits in cash ( $\%$ of GDP) } \\
\hline \multicolumn{3}{|l|}{ Family benefits in kind ( $\%$ of GDP) } \\
\hline \multicolumn{3}{|l|}{ Number of weeks of maternity leave } \\
\hline \multicolumn{3}{|l|}{ Pension system - primarily affecting the elderly } \\
\hline \multicolumn{3}{|l|}{ Legal age for pensions (total) } \\
\hline Error correction term & \multicolumn{2}{|c|}{$-0.257^{\star *}$} \\
\hline Adjusted R-squared & .964 & .674 \\
\hline Country / year fixed effects & Yes / Yes & Yes / Yes \\
\hline No. of observations / countries & \multicolumn{2}{|c|}{$422 / 25$} \\
\hline Years & \multicolumn{2}{|c|}{$1987-2010$} \\
\hline
\end{tabular}

Note: The regression is run using dynamic OLS and the employment rate for the working age population (age 15-64) as the dependent variable and the policies and control variables as explanatory variables. Heteroskedasticity and autocorrelation robust (Newey-West) standard errors are shown in parentheses. The regressions also include the output gap, government employment, the government budget balance, a measure of average educational attainment (adjusted mean years of schooling) and an indicator for the presence of minimum wages as further controls. See more details and Gal and Theising (2015). ${ }^{* *}$ Denotes significance at the $5 \%$ and ${ }^{*}$ and the $10 \%$ level, respectively. 
Table A4.4 Employment rate - long- and short run effects by skill levels

Explanatory variables

\begin{tabular}{|c|c|c|c|c|c|c|}
\hline \multirow[t]{3}{*}{ Explanatory variables } & \multicolumn{6}{|c|}{ Dependent variable: employment rate } \\
\hline & \multicolumn{2}{|c|}{ Low skilled } & \multicolumn{2}{|c|}{ Medium skilled } & \multicolumn{2}{|c|}{ High skilled } \\
\hline & Long-run & Short-run & Long-run & Short-run & Long-run & Short-run \\
\hline \multicolumn{7}{|l|}{ Tax-benefit and activation policies } \\
\hline UE benefit replacement rate & $-0.160^{\star \star}$ & -0.030 & $-0.087^{\star \star}$ & 0.024 & -0.030 & -0.001 \\
\hline $\begin{array}{l}\text { ALMP spending on unemployed, } \\
\text { as \% of GDP/capita (HP-trend) }\end{array}$ & -0.001 & 0.032 & -0.029 & $0.083^{\star *}$ & $-0.044^{\star}$ & 0.036 \\
\hline Tax wedge (couple, $2 \mathrm{ch}$.) & -0.030 & -0.014 & $-0.268^{\star *}$ & $-0.090^{\star *}$ & -0.034 & 0.000 \\
\hline \multicolumn{7}{|l|}{ Wage setting institutions } \\
\hline Excess coverage & $-0.242^{* \star}$ & -0.053 & $-0.233^{\star *}$ & -0.000 & $-0.103^{*}$ & 0.003 \\
\hline Excess coverage * Tax wedge (couple, 2 ch.) & -0.512 & -0.333 & 0.348 & -0.064 & $1.217^{\star \star}$ & 0.105 \\
\hline Minimum wage (\%median) & -0.124 & -0.004 & -0.025 & -0.043 & -0.117 & -0.016 \\
\hline \multicolumn{7}{|l|}{ Labour and product market regulations } \\
\hline EPL regular contracts & $-5.223^{\star \star}$ & -0.223 & $-4.673^{\star \star}$ & 0.540 & $2.643^{*}$ & $1.285^{\star \star}$ \\
\hline ETC regulation & 0.345 & 0.090 & $-2.214^{\star *}$ & -0.401 & -0.387 & -0.411 \\
\hline Error correction term & \multicolumn{2}{|c|}{$-0.347^{\star \star}$} & \multicolumn{2}{|c|}{$-0.225^{\star *}$} & \multicolumn{2}{|c|}{$-0.297^{\star *}$} \\
\hline Adjusted R-squared & 0.981 & .391 & .964 & .505 & .886 & 0.300 \\
\hline Country / year fixed effects & \multicolumn{6}{|c|}{ Yes / Yes } \\
\hline No. of observations / countries & \multicolumn{6}{|c|}{327 / 24} \\
\hline Years & \multicolumn{6}{|c|}{$1990-2010$} \\
\hline
\end{tabular}

Note: The regression is run using dynamic OLS and the employment rate for the working age population (age 15-64) by educational attainment levels, approximating skill levels (primary, secondary and tertiary), as the dependent variable and the policies and control variables as explanatory variables. The regressions also include the output gap, government employment, the government budget balance, a measure of average educational attainment (adjusted mean years of schooling) and an indicator for the presence of minimum wages as further controls. Heteroskedasticity and autocorrelation robust (Newey-West) standard errors are shown in parentheses. See more details and Gal and Theising (2015). ${ }^{* *}$ Denotes significance at the $5 \%$ and ${ }^{*}$ and the $10 \%$ level, respectively. 


\section{APPENDIX 5. ALTERNATIVE REFORM SCENARIOS}

1. There are two main types of reform intensity scenarios discussed below. The first captures policy changes observed in the past (within countries). The second assumes a reduction in cross-country differences in policy settings (Table A5.1).

\section{Typically observed policy changes in the past}

2. Policy effects are estimated using regressions that include country-fixed effects. Country-fixed effects capture all the cross-sectional differences in policies. Hence, the coefficient estimates on policies show only policy effect over time (and averaged across countries). To reflect this nature of the estimated policy effects, within-country policy-change scenarios only consider past average changes in policies over time but not across countries.

- Average improvements in the policy indicators over 2 or 5 years (Table A5.1, columns 2 and 3).

- For the two-year change, only those two consecutive years are used when the policy indicator moves into the "good" (reform) direction in both years.

- The definition at the 5-year horizon is more flexible: policies do not need to show improvement every year but only over five years. Assuming policy improvements in 5 consecutive years do not appear very plausible and would limit strongly our sample.

- Average changes can be further split into small and large reforms: they can be captured, for instance, by the $25^{\text {th }}$ and the $75^{\text {th }}$ percentile of policy indicator changes, respectively in the "favourable" directions.

- Average changes in the policy indicator (measured by average within country standard deviation). This scenario reflects average policy changes (both improvements and fall-backs) for the average country over the sample period (Table A5.1, column 1).

\section{Policy changes calibrated based on cross-country differences}

3. A reduction in the gap from the best performers. This scenario shows how much a change would be needed in a given policy area to close $20 \%$ of the gap to the average of the three best performing countries. The implied policy changes are shown for the average country and for poor performers (the bottom quartile of the distribution) (Table A5.1, columns 4 and 5).

4. Favourable policy changes at a 2-year horizon are typically smaller than those at 5 years. For instance, changes in ALMP spending, ETCR and the legal retirement age double. Also, direction-neutral policy changes (captured by standard deviations) tend to be larger than positive reforms at the 5-year horizon. The few exceptions to these general observations are corporate taxes and maternity leave where short-term changes dominate the longer-term ones. For EPL, changes are broadly comparable for all three scenarios.

5. Closing the gap to the frontier countries implies considerably larger policy changes than scenarios reflecting average policy changes over time. Reform efforts based on assuming only a partial (20\%) reduction in the gap are much closer to observed past reform efforts, but they still tend to be 
somewhat larger. EPL and other labour market policies targeting specific demographic groups are the few exceptions when the two approaches give broadly similar magnitudes. For ETCR and corporate taxes, past reforms are greater than those implied by the 20\% gap reduction (Table A5.1). Against this background, reform intensity measures derived from cross-country variation should be taken with caution in policy simulations: they are larger than changes observed in the past. Coefficient estimates obtained on the basis of historical data might not hold for these large variations.

Table A5.1. Alternative measures for structural reforms

\begin{tabular}{|c|c|c|c|c|c|c|}
\hline \multirow[t]{3}{*}{$\begin{array}{l}\text { Structural policy } \\
\text { areas }\end{array}$} & \multicolumn{3}{|c|}{$\begin{array}{l}\text { Typically observed policy } \\
\text { changes in the past }\end{array}$} & \multicolumn{3}{|c|}{$\begin{array}{l}\text { Reducing the gap with the best } \\
\text { performers }\end{array}$} \\
\hline & \multirow{2}{*}{$\begin{array}{l}\text { Average } \\
\text { changes } \\
\text { over time* }^{*}\end{array}$} & \multicolumn{2}{|c|}{$\begin{array}{c}\text { Average } \\
\text { improvements over }\end{array}$} & \multirow{2}{*}{$\begin{array}{c}\text { By } 100 \% \text {, } \\
\text { from the } \\
\text { average }\end{array}$} & \multicolumn{2}{|c|}{ By $20 \%$} \\
\hline & & $\begin{array}{l}2 \text { year } \\
\text { periods }\end{array}$ & $\begin{array}{l}5 \text { year } \\
\text { periods }\end{array}$ & & $\begin{array}{l}\text { from the } \\
\text { average }\end{array}$ & $\begin{array}{l}\text { from a poor } \\
\text { performer** }\end{array}$ \\
\hline \multicolumn{7}{|l|}{ Product market regulation } \\
\hline $\operatorname{ETCR}(0-6,6$ is strictest $)$ & -1.25 & -0.31 & -0.70 & -0.83 & -0.17 & -0.24 \\
\hline \multicolumn{7}{|l|}{ Intermediate policy channels for productivity } \\
\hline Openness (perc. of GDP) & 6.86 & 4.01 & 5.07 & 33.45 & 6.69 & 9.44 \\
\hline R\&D (business exp.) (perc. of GDP) & 0.23 & 0.10 & 0.16 & 1.91 & 0.38 & 0.51 \\
\hline \multicolumn{7}{|l|}{ Investment specific policies } \\
\hline Corporate tax (as perc. of GDP) & -0.99 & -0.98 & -0.76 & -1.33 & -0.27 & -0.31 \\
\hline \multicolumn{7}{|l|}{ Labour market policies } \\
\hline \multicolumn{7}{|l|}{ Labour market regulations } \\
\hline EPL (regular contr., $0-6,6$ is strictest) & -0.19 & -0.30 & -0.28 & -1.29 & -0.26 & -0.33 \\
\hline \multicolumn{7}{|l|}{ Tax-benefit and activation policies } \\
\hline Unemployment benefits (perc. of earnings) & -5.02 & -1.42 & -2.70 & -17.19 & -3.44 & -5.27 \\
\hline $\begin{array}{l}\text { ALMP spending (per unemployed, as } \\
\text { perc. of GDP/capita) }\end{array}$ & 12.51 & 3.18 & 5.85 & 22.50 & 4.50 & 7.00 \\
\hline Tax wedge (perc.points) & -3.34 & -2.28 & -2.96 & -26.58 & -5.32 & -7.09 \\
\hline Tax wedge (single) (perc.points) & -2.40 & -1.39 & -1.79 & -18.33 & -3.67 & -4.64 \\
\hline \multicolumn{7}{|l|}{ Wage setting institutions } \\
\hline Excess coverage (perc.points) & -4.99 & -1.89 & -3.03 & -26.51 & -5.30 & -8.67 \\
\hline Minimum wage (perc. of median) & -4.68 & -2.48 & -3.45 & -10.23 & -2.05 & -3.26 \\
\hline \multicolumn{7}{|c|}{ Labour market policies for specific demographic groups } \\
\hline Family benefits in kind (perc. of GDP) & 0.26 & 0.11 & 0.19 & 0.33 & 0.07 & 0.11 \\
\hline Maternity leave weeks & 2.79 & 4.83 & 4.39 & 20.32 & 4.06 & 4.80 \\
\hline Legal retirement age & 1.18 & 0.57 & 1.15 & 2.17 & 0.43 & 0.72 \\
\hline
\end{tabular}

Notes: * Measured by the within-country standard deviation, averaged across countries. As the standard deviation is always positive, it is multiplied by -1 if a favourable change in the policy indicator is a negative one (ETCR, EPL).

${ }^{* *}$ A poor performer is measured as the lowest $25^{\text {th }}$ percentile in the distribution of policy stances in the last available year.

Past policy changes are calculated for the period from 1985 to 2011-2013 (depending on data availability). Policy changes based on the gap reduction are calculated using the last available year for each indicator. The calculations are carried out for the 25 OECD countries for which the labour market indicators are available. Australia, Austria, Belgium, Canada, Czech Republic, Denmark, Finland, France, Germany, Greece, Hungary, Italy, Japan, Korea, Netherlands, New Zealand, Norway, Poland, Portugal, Slovak Republic, Spain, Sweden, Switzerland, United Kingdom, United States. See Egert (2016a, b) and Gal and Theising (2015) for more details. 


\section{APPENDIX 6: ADDITIONAL DESCRIPTIVE AND RESULT TABLES}

Table A6.1. Further potential reform measures

\begin{tabular}{|c|c|c|c|c|c|c|c|c|}
\hline \multirow[b]{2}{*}{$\begin{array}{l}\text { Structural policy } \\
\text { areas }\end{array}$} & \multirow{2}{*}{$\begin{array}{c}\text { Reform } \\
\text { direction }\end{array}$} & \multicolumn{3}{|c|}{ 2-year change } & \multicolumn{3}{|c|}{ 5-year change } & \multirow{2}{*}{$\begin{array}{c}\text { From } \\
\text { average to } \\
3 \text { best }\end{array}$} \\
\hline & & $\begin{array}{c}\text { Average } \\
\text { reform }\end{array}$ & $\begin{array}{l}\text { Small } \\
\text { reform }\end{array}$ & $\begin{array}{l}\text { Large } \\
\text { reform }\end{array}$ & $\begin{array}{l}\text { Averag } \\
\text { e reform }\end{array}$ & $\begin{array}{c}\text { Small } \\
\text { reform }\end{array}$ & $\begin{array}{l}\text { Large } \\
\text { reform }\end{array}$ & \\
\hline Unemployment benefits & - & -1.42 & -0.32 & -1.51 & -2.70 & -0.63 & -3.09 & -17.19 \\
\hline ALMP spending & + & 3.18 & 1.03 & 3.73 & 5.85 & 1.54 & 6.69 & 22.50 \\
\hline Tax wedge & - & -2.28 & -0.79 & -2.79 & -2.96 & -0.97 & -3.77 & -26.58 \\
\hline Tax wedge (single) & - & -1.39 & -0.54 & -1.81 & -1.79 & -0.63 & -2.58 & -18.33 \\
\hline Excess coverage & - & -1.89 & -0.44 & -2.67 & -3.03 & -0.55 & -3.86 & -26.51 \\
\hline Minimum wage & - & -2.48 & -1.00 & -2.95 & -3.45 & -1.40 & -4.20 & -10.23 \\
\hline EPL & - & -0.30 & -0.02 & -0.25 & -0.28 & -0.10 & -0.33 & -1.29 \\
\hline ETCR & - & -0.31 & -0.11 & -0.44 & -0.70 & -0.35 & -1.00 & -0.83 \\
\hline Family benefits in kind & + & 0.11 & 0.03 & 0.14 & 0.19 & 0.05 & 0.30 & 0.33 \\
\hline Maternity leave weeks & + & 4.83 & 3.14 & 4.00 & 4.39 & 1.14 & 6.00 & 20.32 \\
\hline Legal retirement age & + & 0.57 & 0.26 & 0.51 & 1.15 & 0.50 & 1.30 & 2.17 \\
\hline Openness & + & 4.01 & 1.71 & 5.15 & 5.07 & 1.88 & 6.63 & 33.45 \\
\hline R\&D (business exp.) & + & 0.10 & 0.03 & 0.13 & 0.16 & 0.05 & 0.22 & 1.91 \\
\hline Corporate tax & - & -0.98 & -0.50 & -1.25 & -0.76 & -0.30 & -1.00 & -1.33 \\
\hline
\end{tabular}

Note: The columns referring to 2-year and 5-year changes are averages across all countries and years for such 2-year and 5-year windows (cumulative changes) where the cumulative direction of change in the policy indicator corresponds to a "reform direction". Moreover, for 2-year change, the indicators are required to signal a reform both from $t-2$ to $t-1$ as well as from $t-1$ to $t$. Small and large reforms capture the $25^{\text {th }}$ and $75^{\text {th }}$ percentile of indicator changes (reforms), respectively.

Table A6.2. Basic descriptive statistics on employment rate and the population structure

Average in 2013 across 25 OECD countries (in percentage points)

\begin{tabular}{|c|c|c|c|}
\hline & Overall & $\begin{array}{c}\text { By } \\
\text { demographic } \\
\text { groups } \\
\end{array}$ & $\begin{array}{c}\text { By educational } \\
\text { attainment levels }\end{array}$ \\
\hline $\begin{array}{l}\text { Employment rate for the } \\
\text { working age populatiion } \\
\text { (15-64) }\end{array}$ & 67.1 & & \\
\hline Youth (15-24) & & 17.7 & \\
\hline Prime age female (25-54) & & 31.5 & \\
\hline Prime age male (25-54) & & 31.7 & \\
\hline Elderly (55-64) & & 19.1 & \\
\hline Primary & & & 26.5 \\
\hline Secondary & & & 46.3 \\
\hline Tertiary & & & 27.1 \\
\hline Total & & 100.0 & 100.0 \\
\hline
\end{tabular}


Table A6.3. The impact of reforms on GDP per capita and its supply side components 10 years after the reforms

\begin{tabular}{|c|c|c|c|c|c|}
\hline \multirow[t]{2}{*}{$\begin{array}{l}\text { Structural policy } \\
\text { areas }\end{array}$} & \multirow{2}{*}{$\begin{array}{c}\text { Size of a } \\
\text { typically } \\
\text { observed } \\
\text { reform }\end{array}$} & \multirow{2}{*}{$\begin{array}{c}\text { Total effect } \\
\text { on GDP per } \\
\text { capita }\end{array}$} & \multicolumn{3}{|c|}{$\begin{array}{l}\text { Impact on supply side } \\
\text { components }\end{array}$} \\
\hline & & & MFP & $\mathbf{K} / \mathbf{Y}$ & $\mathbf{L} / \mathbf{N}$ \\
\hline & & in percent & \multicolumn{2}{|c|}{ in percent } & $\begin{array}{l}\text { in percentage } \\
\text { points }\end{array}$ \\
\hline Product market regulation & & $1.02 \%$ & & & \\
\hline $\operatorname{ETCR}(0-6,6$ is strictest) & -0.31 & $1.02 \%$ & $0.74 \%$ & $0.15 \%$ & 0.14 \\
\hline $\begin{array}{l}\text { Intermediate policy channels mainly affe } \\
\text { productivity }\end{array}$ & cting & $1.34 \%$ & & & \\
\hline Openness (perc. of GDP) & 4.01 & $1.17 \%$ & $1.17 \%$ & & \\
\hline R\&D (business exp.) (perc. of GDP) & 0.10 & $0.17 \%$ & $0.17 \%$ & & \\
\hline Investment specific policies & & $0.38 \%$ & & & \\
\hline Corporate tax (as perc. of GDP) & -0.98 & $0.38 \%$ & & $0.77 \%$ & \\
\hline Labour market policies & & $4.03 \%$ & & & \\
\hline Labour market regulations & & $0.57 \%$ & & & \\
\hline EPL (regular contr., $0-6,6$ is strictest) & -0.30 & $0.57 \%$ & & $0.51 \%$ & 0.21 \\
\hline Tax-benefit and activation policies & & $1.74 \%$ & & & \\
\hline Unemployment benefits (perc. of earnings & -1.42 & $0.42 \%$ & & & 0.28 \\
\hline $\begin{array}{l}\text { ALMP spending (per unemployed, as } \\
\text { perc. of GDP/capita) }\end{array}$ & 3.18 & $0.57 \%$ & $0.17 \%$ & & 0.26 \\
\hline Tax wedge (perc.points) & -2.28 & $0.45 \%$ & & & 0.30 \\
\hline Tax wedge (single) (perc.points) & -1.39 & $0.31 \%$ & & & 0.20 \\
\hline Wage setting institutions & & $0.79 \%$ & & & \\
\hline Excess coverage (perc.points) & -1.89 & $0.14 \%$ & & & 0.09 \\
\hline Minimum wage (perc. of median) & -2.48 & $0.66 \%$ & & & 0.43 \\
\hline $\begin{array}{l}\text { Labour market policies for } \\
\text { specific demographic groups }\end{array}$ & & $0.92 \%$ & & & \\
\hline Family benefits in kind (perc. of GDP) & 0.11 & $0.23 \%$ & & & 0.15 \\
\hline Maternity leave weeks & 4.83 & $0.57 \%$ & & & 0.38 \\
\hline Legal retirement age & 0.57 & $0.13 \%$ & & & 0.09 \\
\hline
\end{tabular}

Note: Typically observed reforms are measured here by the average of all beneficial two-year policy changes that were observed over two consecutive years in the sample. ${ }^{*}$ The total GDP/capita effect uses the employment effects from the aggregation across demographic groups (last column), and it uses the formula in eq. (5) to aggregate across supply side components. The employment rate effects are transformed from percentage points to percent by using the average employment rate and the education and demographic structure in the sample in the last observable year (67\% in 2013). The reform measures are calculated for the period starting in 1985 until the latest available year (typically around 2011-2013). The country coverage is 25 OECD countries for which the labour market indicators are available. See more details in Egert (2016a, b) and Gal and Theising (2015). 
Table A6.4. The total long-run impact of reforms on GDP per capita and its supply side components

\begin{tabular}{|c|c|c|c|c|c|}
\hline \multirow[t]{2}{*}{$\begin{array}{l}\text { Structural policy } \\
\text { areas }\end{array}$} & \multirow{2}{*}{$\begin{array}{c}\text { Size of a } \\
\text { typically } \\
\text { observed } \\
\text { reform }\end{array}$} & \multirow{2}{*}{$\begin{array}{c}\text { Total effect } \\
\text { on GDP per } \\
\text { capita }\end{array}$} & \multicolumn{3}{|c|}{$\begin{array}{l}\text { Impact on supply side } \\
\text { components }\end{array}$} \\
\hline & & & MFP & $\mathbf{K} / \mathbf{Y}$ & $\mathbf{L} / \mathbf{N}$ \\
\hline & & in percent & \multicolumn{2}{|c|}{ in percent } & $\begin{array}{c}\text { in percentage } \\
\text { points }\end{array}$ \\
\hline Product market regulation & & $2.09 \%$ & & & \\
\hline ETCR $(0-6,6$ is strictest $)$ & -0.31 & $2.09 \%$ & $1.44 \%$ & $0.86 \%$ & 0.15 \\
\hline $\begin{array}{l}\text { Intermediate policy channels mainly affe } \\
\text { productivity }\end{array}$ & cting & $2.86 \%$ & & & \\
\hline Openness (perc. of GDP) & 4.01 & $2.40 \%$ & $2.40 \%$ & & \\
\hline R\&D (business exp.) (perc. of GDP) & 0.10 & $0.46 \%$ & $0.46 \%$ & & \\
\hline Investment specific policies & & $1.25 \%$ & & & \\
\hline Corporate tax (as perc. of GDP) & -0.98 & $1.25 \%$ & & $2.55 \%$ & \\
\hline Labour market policies & & $5.78 \%$ & & & \\
\hline Labour market regulations & & $1.83 \%$ & & & \\
\hline EPL (regular contr., $0-6,6$ is strictest) & -0.30 & $1.83 \%$ & & $2.93 \%$ & 0.26 \\
\hline Tax-benefit and activation policies & & $2.10 \%$ & & & \\
\hline Unemployment benefits (perc. of earnings & -1.42 & $0.45 \%$ & & & 0.30 \\
\hline $\begin{array}{l}\text { ALMP spending (per unemployed, as } \\
\text { perc. of GDP/capita) }\end{array}$ & 3.18 & $0.85 \%$ & $0.46 \%$ & & 0.26 \\
\hline Tax wedge (perc.points) & -2.28 & $0.47 \%$ & & & 0.31 \\
\hline Tax wedge (single) (perc.points) & -1.39 & $0.32 \%$ & & & 0.21 \\
\hline Wage setting institutions & & $0.86 \%$ & & & \\
\hline Excess coverage (perc.points) & -1.89 & $0.15 \%$ & & & 0.10 \\
\hline Minimum wage (perc. of median) & -2.48 & $0.70 \%$ & & & 0.46 \\
\hline $\begin{array}{l}\text { Labour market policies for } \\
\text { specific demographic groups }\end{array}$ & & $0.99 \%$ & & & \\
\hline Family benefits in kind (perc. of GDP) & 0.11 & $0.24 \%$ & & & 0.16 \\
\hline Maternity leave weeks & 4.83 & $0.61 \%$ & & & 0.40 \\
\hline Legal retirement age & 0.57 & $0.14 \%$ & & & 0.09 \\
\hline
\end{tabular}

Note: Typically observed reforms are measured here by the average of all beneficial two-year policy changes that were observed over two consecutive years in the sample. *The total GDP/capita effect uses the employment effects from the aggregation across demographic groups (last column), and it uses the formula in eq. (5) to aggregate across supply side components. The employment rate effects are transformed from percentage points to percent by using the average employment rate and the education and demographic structure in the sample in the last observable year (67\% in 2013). The reform measures are calculated for the period starting in 1985 until the latest available year (typically around 2011-2013). The country coverage is 25 OECD countries for which the labour market indicators are available. See more details in Egert (2016a, b) and Gal and Theising (2015). 